\title{
Physiological Phenotype and Vulnerability in Parkinson's Disease
}

\author{
D. James Surmeier ${ }^{1}$, Jaime N. Guzman ${ }^{1}$, Javier Sanchez ${ }^{1}$, and Paul T. Schumacker ${ }^{2}$ \\ ${ }^{1}$ Department of Physiology, Northwestern University, Chicago, Illinois 60611 \\ ${ }^{2}$ Pediatrics, Feinberg School of Medicine, Northwestern University, Chicago, Illinois 60611 \\ Correspondence: j-surmeier@northwestern.edu
}

This review will focus on the principles underlying the hypothesis that neuronal physiological phenotype- - how a neuron generates and regulates action potentials—-makes a significant contribution to its vulnerability in Parkinson's disease (PD) and aging. A cornerstone of this hypothesis is that the maintenance of ionic gradients underlying excitability can pose a significant energetic burden for neurons, particularly those that have sustained residence times at depolarized membrane potentials, broad action potentials, prominent $\mathrm{Ca}^{2+}$ entry, and modest intrinsic $\mathrm{Ca}^{2+}$ buffering capacity. This energetic burden is shouldered in neurons primarily by mitochondria, the sites of cellular respiration. Mitochondrial respiration increases the production of damaging superoxide and other reactive oxygen species (ROS) that have widely been postulated to contribute to cellular aging and PD. Many of the genetic mutations and toxins associated with PD compromise mitochondrial function, providing a mechanistic linkage between known risk factors and cellular physiology that could explain the pattern of pathology in PD. Because much of the mitochondrial burden created by this atrisk phenotype is created by $\mathrm{Ca}^{2+}$ entry through L-type voltage-dependent channels for which there are antagonists approved for human use, a neuroprotective strategy to reduce this burden is feasible.

Parkinson's disease (PD) is a disabling neurodegenerative disorder that is strongly associated with aging, increasing exponentially in incidence above the age of 65 (de Rijk et al. 1997; de Lau et al. 2004). Currently, there is no therapeutic strategy that is proven to slow or stop disease progression. Without a neuroprotective treatment, the incidence of $\mathrm{PD}$ is expected to increase dramatically worldwide in the coming decades as life expectancy increases (Dorsey et al. 2007). This will pose an enormous monetary and human burden on society.
The best hope for developing a neuroprotective treatment lies in a better understanding of disease pathogenesis. In the last two decades there has been a great deal of progress in identifying genetic risk factors for PD (Cookson 2010; Cookson and Bandmann 2010; Wider et al. 2010). There is the reasonable belief that identifying the consequences of these mutations will lead to new therapeutic strategies, perhaps ones specifically designed for a particular mutation. However, the vast majority of PD cases are not associated with any known genetic

Editor: Serge Przedborski

Additional Perspectives on Parkinson's Disease available at www.perspectivesinmedicine.org

Copyright (C) 2012 Cold Spring Harbor Laboratory Press; all rights reserved; doi: 10.1101/cshperspect.a009290 Cite this article as Cold Spring Harb Perspect Med 2012;2:a009290 
D.J. Surmeier et al.

mutations. Genome-wide association studies (GWAS) promise to put disease risk in these cases on a firmer genetic footing (Gubitz and Gwinn 2009). The working hypothesis of these studies is that the proteins linked to risk-increasing polymorphisms will begin to segregate into well-defined subcellular systems, providing insight into pathogenesis.

Although potentially providing important information about pathogenic mechanisms, these studies will not explain the distribution of neuron loss or pathology in PD. This pattern will be determined by epigenetic factors. Unfortunately, this relationship is not likely to be a simple one, as the expression pattern genes linked to PD do not predict the pattern of pathology. Hence, it must be that other phenotypic factors govern the functional consequences of PDlinked mutations and polymorphisms. Neurons and the networks they form can be viewed as very specialized systems that create the context in which PD-linked mutations manifest themselves. Understanding why neural systems are vulnerable to these mutations could provide a clear path to therapeutic intervention.

This review focuses on one distinctive feature of neural systems, excitability. The energetic demands that attend the maintenance of electrochemical ionic gradients necessary for excitability could be a key determinant of vulnerability. Although plausible, this in and of itself would not point to a therapy, as there is no obvious way to change this characteristic without broadly compromising brain function. But the pathology in PD is not found in all neurons. The most widely accepted pathological marker in PD is the Lewy body (LB) or Lewy neurite (LN), a proteinaceous intracellular deposition (Braak et al. 2004). If LB/LNs are used as a PD marker, it is clear that the pathology is not randomly distributed and far from ubiquitous. In fact, the percentage of brain neurons affected through the mid-stages of the disease appears to be far less than $1 \%$. Moreover, this fraction of LB/LN-containing neurons is not randomly distributed in the brain; rather, these neurons reside in reasonably well-defined nuclei with different functional roles, suggesting that physiological phenotype confers risk. This is an im- portant clue about the mechanisms that bring out the pathological consequences of factors that affect most if not all neurons (i.e., age, mutations in widely expressed genes, and toxins).

\section{THE NEURONAL PHENOTYPE}

PD is a disease of neurons, not of the liver, kidney, or heart. An implication of this fact is that one or more of the features distinguishing neurons from these other cell types must contribute in a seminal way to pathogenesis. What then distinguishes neurons? A cardinal feature of neurons that separates them from nearly all other cell types is excitability. Neurons use a steep electrochemical gradient across their plasma membrane to perform computations on incoming chemical signals from other neurons and to pass the outcome of this computation to other neurons. Chemical signaling between neurons is for the most part accomplished at specialized junctions between neurons called synapses where a presynaptic transmitter release site is paired with a postsynaptic site at which receptors for the transmitter are aggregated. Effective synaptic transmission between neurons depends on the maintenance of electrochemical gradients for $\mathrm{Na}^{+}, \mathrm{K}^{+}, \mathrm{Ca}^{2+}$, and $\mathrm{Cl}^{-}$across the plasma membrane. By gating the flow of one or more of these ions, ionotropic receptors generate electrical signals that are integrated by the postsynaptic neuron. Consider the principal excitatory transmitter in the brain, glutamate. Excitatory synaptic transmission mediated by ionotropic glutamate receptors depends on the electrochemical gradient for both $\mathrm{Na}^{+}$and $\mathrm{Ca}^{2+}$. Most AMPA receptors (AMPARs) are selectively permeable to $\mathrm{Na}^{+}$ions. When 2-amino-3-(5-methyl-3-oxo-1,2-oxazol-4-yl)propanoic acid (AMPA) receptors are activated, they open a pore that allows $\mathrm{Na}^{+}$ions to flow into the electronegative cytoplasm, depolarizing the membrane. N-Methyl-D-aspartate (NMDA) receptors (NMDARs) are permeable to both $\mathrm{Na}^{+}$ and $\mathrm{Ca}^{2+}$ ions, allowing them to not only depolarize the membrane, but to initiate intracellular signaling cascades dependent on $\mathrm{Ca}^{2+}$. An important feature that distinguishes NMDARs is that they require membrane depolarization (in 
addition to ligand binding) to conduct (depolarization dislodges $\mathrm{Mg}^{2+}$ ions from the pore). In most neurons, the resting membrane potential is more negative that the voltage at which $\mathrm{Mg}^{2+}$ dislodges, effectively reducing the opening of NMDARs during routine excitatory synaptic events.

\section{SPIKING POSES A METABOLIC BURDEN}

The outcome of the computation performed by a neuron in response to synaptic events is coded in a pattern of regenerative events called action potentials or spikes. Spikes are transient regen- erative events that rely on the transmembrane electrochemical gradients for $\mathrm{Na}^{+}, \mathrm{K}^{+}$, and $\mathrm{Ca}^{2+}$ ions (Fig. 1). In most neurons, the spike is triggered by the opening of voltage-dependent membrane pores or channels that are selectively permeable to $\mathrm{Na}^{+}$ions, allowing positively charged $\mathrm{Na}^{+}$ions to move from the extracellular space into the cytosol. This redistribution of charge pushes the transmembrane potential from relatively negative membrane potentials to near $0 \mathrm{mV}$. This depolarization causes voltage-dependent channels that are selectively permeable to $\mathrm{K}^{+}$ions to open, resulting in the movement of positively charged $\mathrm{K}^{+}$

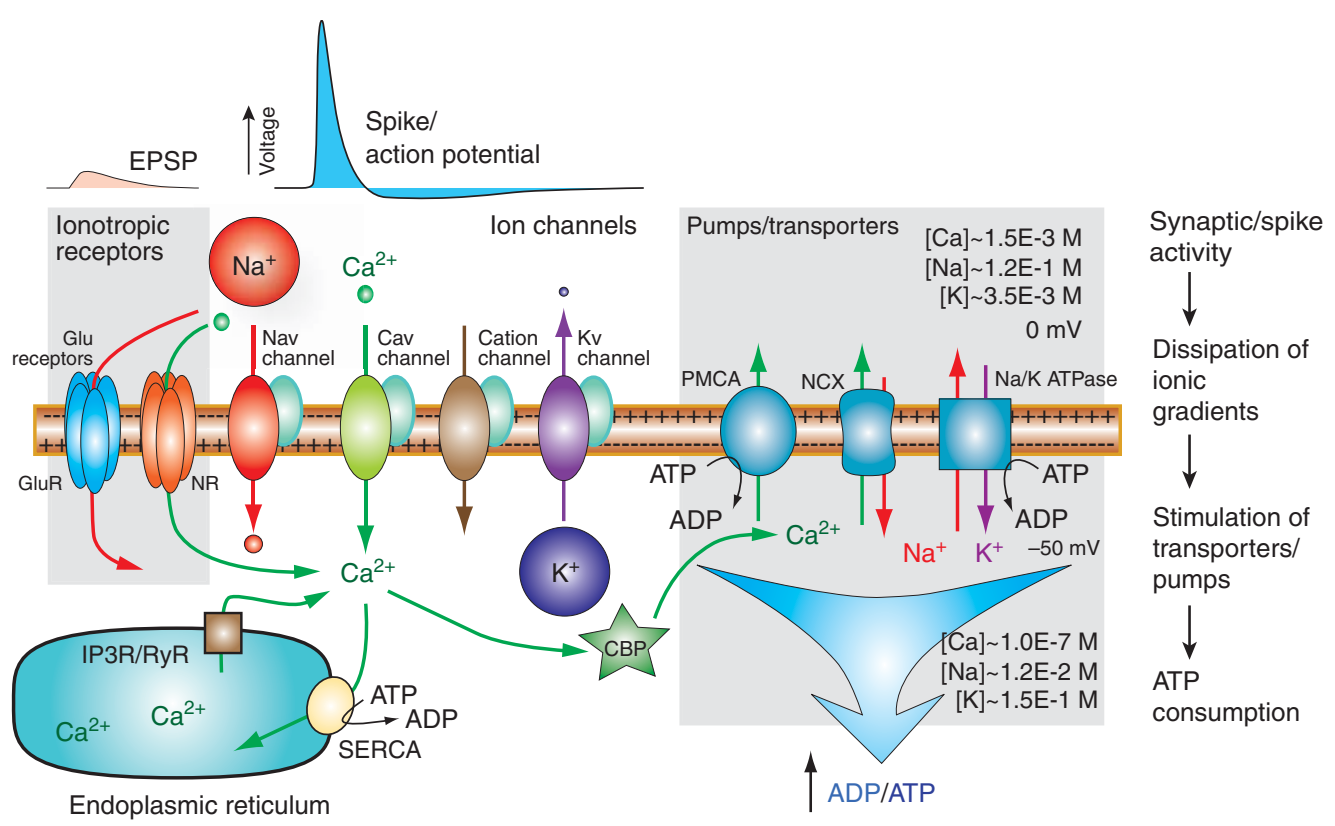

Figure 1. Schematic representation of the plasma proteins that regulate ionic gradients following neurotransmitter release or during the time course of an action potential spike. Synaptic input and spiking dissipate ionic gradients maintained by pumps and exchangers creating a metabolic burden. Illustrated in the model are the classic influx and efflux of ions favored by their electrochemical gradients. Particularly, the electrochemical gradient for $\mathrm{Ca}^{2+}\left(\sim+128 \mathrm{mV}\right.$ under physiological conditions) favors a strong influx of $\mathrm{Ca}^{2+}$ ions through NMDA receptors (NR) following glutamate release or activation of $\mathrm{Ca}_{\mathrm{v}}$ channels during pacemaking spiking activity. The tight regulation of intracellular $\mathrm{Ca}^{2+}$ is routed into the endoplasmic reticulum (ER) via sarco(endo)plasmic reticulum $\mathrm{Ca}^{2+}$-ATPase (SERCA) pumps. However, $\mathrm{Ca}^{2+}$ influx into the ER can trigger the process of $\mathrm{Ca}^{2+}$-induced $\mathrm{Ca}^{2+}$ release (CICR), displayed here as $\mathrm{Ca}^{2+}$ released through the IP3R/RyR pathway. Another venue of regulation of $\mathrm{Ca}^{2+}$ depends on whether the cell expresses $\mathrm{Ca}^{2+}$-binding proteins (CBP), which help buffer intracellular $\mathrm{Ca}^{2+}$. Whether CBP is present or not, $\mathrm{Ca}^{2+}$ can also be extruded out of the cell via plasma membrane $\mathrm{Ca}^{2+}$-ATPase (PMCA) or $\mathrm{Na}^{+} / \mathrm{Ca}^{2+}$ exchanger (NCX) proteins. SERCA, PMCA, NCX, and the $\mathrm{Na} /$ K ATPase all require ATP as the energy source to maintain these gradients, and this ATP consumption can have a strong impact on the bioenergetics of the cell to maintain normal levels of intracellular $\mathrm{Ca}^{2+}$. 
D.J. Surmeier et al.

ions in the opposite direction: from the cytosol to the extracellular space, reestablishing the potential gradient. This sequence of events requires that the concentration of $\mathrm{Na}^{+}$ions be low in the cytosol, but the concentration of $\mathrm{K}^{+}$ions high.

In most neurons, spikes are initiated in a specialized region at the junction between the cell body and the axon called the axon initial segment (AIS). The AIS is specialized in several respects, most notably in the concentration of voltage-dependent $\mathrm{Na}^{+}$channels. Spikes initiated in the AIS propagate both down the axon to synaptic terminals (where they initiate transmitter release) and into the somatodendritic region, creating a spatially distributed dissipation of the transmembrane electrochemical $\mathrm{Na}^{+}$ and $\mathrm{K}^{+}$gradients.

Another cation that crosses the plasma membrane during spikes is the $\mathrm{Ca}^{2+}$ ion. In most neurons, voltage-dependent $\mathrm{Ca}^{2+}$ channels are opened only by strong depolarization during the spike. With repolarization of the membrane potential, these channels slowly close, creating a period during which the driving force for influx of $\mathrm{Ca}^{2+}$ is large and the conductance remains high. This creates a "double hump" in the $\mathrm{Ca}^{2+}$ influx during a spike and makes the total $\mathrm{Ca}^{2+}$ influx during a spike very sensitive to spike duration (Fig. 2). $\mathrm{Ca}^{2+}$ entering during the spike serves a number of ends (Clapham 2007). One is activation of $\mathrm{K}^{+}$channels that help repolarize the membrane potential and impede the generation of another spike for some period of time (refractory period). This interaction takes place in a spatially restricted zone close to the plasma membrane. Neurons that need to spike at high frequencies typically restrict $\mathrm{Ca}^{2+}$ entry by keeping spikes very brief $(<1 \mathrm{~ms})$; $\mathrm{Ca}^{2+}$ entry during the spike is exquisitely dependent on the duration of the spike itself, which varies considerably from one cell type to the next (Fig. 2). To help manage $\mathrm{Ca}^{2+}$, neurons often express fixed $\mathrm{Ca}^{2+}$ buffering proteins (Augustine et al. 2003; Mattson 2007), such as parvalbumin, in addition to the $\mathrm{Ca}^{2+}$ signaling proteins (Clapham 2007).

Exchangers and pumps are responsible for maintaining the electrochemical gradients for
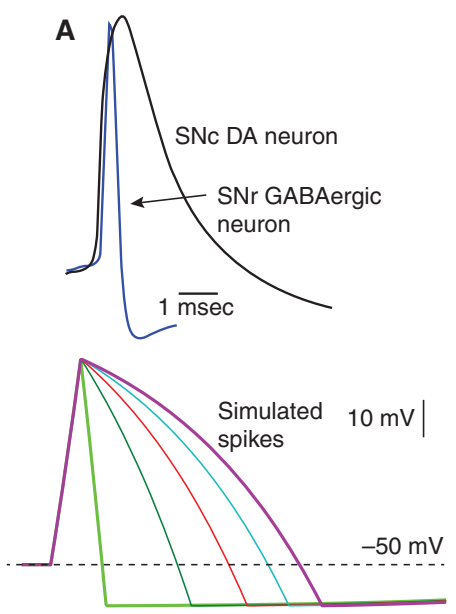

B Simulated calcium currents

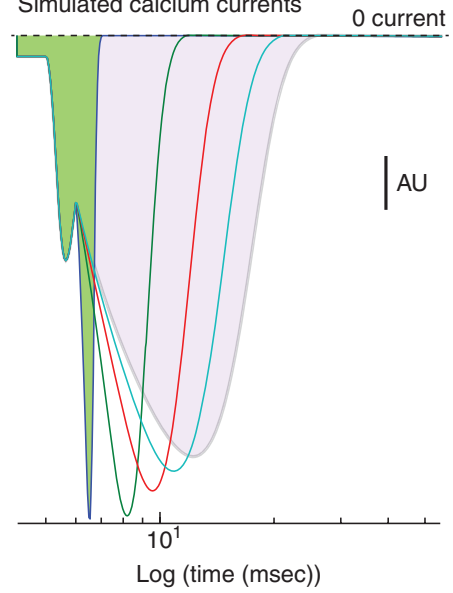

Figure 2. Spike width shapes $\mathrm{Ca}^{2+}$ entry. (A) Spikes recorded from a substantia nigra pars reticulata $(\mathrm{SNr})$ GABAergic neuron and a substantia nigra pars compacta (SNc) dopaminergic neuron (DA). SNc DA neurons have wider spikes compared to SNr GABAergic neurons. (B) In the top panel, simulated spikes of varying width using the computer program Neuron are shown. In the bottom panel, $\mathrm{Ca}^{2+}$ currents were generated in the model in response to the simulated spikes. Simulated $\mathrm{Ca}^{2+}$ currents were evoked by opening of $\mathrm{Ca}_{\mathrm{v}} 1.3$ and $\mathrm{Ca}_{\mathrm{v}} 2.1$ model channels in Neuron. The color-coding of the simulated spikes and respective $\mathrm{Ca}^{2+}$ currents show that the amount of $\mathrm{Ca}^{2+}$ charges that enter the cell is higher in simulated spikes with largest width. This model supports our hypothesis that SNc DA neurons that have large spike width will allow more $\mathrm{Ca}^{2+}$ entry compared to an SNr GABAergic neuron, which then can have a strong impact on the undergoing $\mathrm{Ca}^{2+}$ signaling, handling, and metabolic demands for neuronal populations that can differ based on spike waveform. 
$\mathrm{Na}^{+}, \mathrm{K}^{+}, \mathrm{Ca}^{2+}$, and $\mathrm{Cl}^{-}$. These transmembrane proteins fall into two broad categories. The first are pumps that rely on adenosine triphosphate (ATP) to drive the movement of ions. Pumps that fall into this category include the $\mathrm{Na}^{+} / \mathrm{K}^{+}$ ATPase, the plasma membrane $\mathrm{Ca}^{2+}$ ATPase (PMCA), and the smooth endoplasmic reticulum $\mathrm{Ca}^{2+}$ ATPase (SERCA). The other category uses the energy stored in an existing electrochemical gradient to move ions. A good example of this type of protein is the $\mathrm{Na}^{+} / \mathrm{Ca}^{2+}$ exchanger (NCX), which under physiological conditions uses the $\mathrm{Na}^{+}$gradient to move $\mathrm{Ca}^{2+}$ ions out of the cytosol. Another exchanger of this type is the $\mathrm{Na}^{+} / \mathrm{Ca}^{2+}-\mathrm{K}^{+}$exchanger (NCKX). Together, this combination of pumps and exchangers maintain the transmembrane ionic gradient for cations (Fig. 1).

Although the molecular events coupling ion movement to ATP hydrolysis are still not fully understood, the thermodynamics of ion movement are worth considering because they establish lower limits on the cost of pumping. For $\mathrm{Na}^{+}$ and $\mathrm{K}^{+}$ions, the concentration differences maintained across the plasma membrane are similar, being 10 - to 30 -fold. In contrast, the concentration difference for the $\mathrm{Ca}^{2+}$ concentration is $\sim 20,000$-fold, being $2 \mathrm{mM}$ in the extracellular space and around $100 \mathrm{nM}$ in the intracellular space. Because the free energy change needed to move an ion from one compartment to another depends on the logarithm of the concentration ratio between the two compartments, $\mathrm{Ca}^{2+}$ should be roughly eight times more energetically expensive than a $\mathrm{Na}^{+}$ion (about four times greater on a per charge basis). The Na,KATPase extrudes three $\mathrm{Na}^{+}$ions and takes up two $\mathrm{K}^{+}$per ATP molecule consumed. The PMCA pumps one $\mathrm{Ca}^{2+}$ molecule out for each ATP consumed. So overall, it takes about one ATP for each $\mathrm{Ca}^{2+}$ ion, and one ATP for every three $\mathrm{Na}^{+}$ions. By this rough calculation, although $\mathrm{Ca}^{2+}$ is more expensive than $\mathrm{Na}^{+}$, it is only about 1.5-2 times more expensive per charge than $\mathrm{Na}^{+}$. Whether the bioenergetic cost of normal $\mathrm{Ca}^{2+}$ influx represents a significant fraction of the metabolic capacity of neurons, remains to be seen.

$\mathrm{Ca}^{2+}$ that is not pumped back out of the neuron rapidly is sequestered in intracellular
Physiological Phenotype in Parkinson's Disease

organelles. The most important of these for $\mathrm{Ca}^{2+}$ homeostasis is the endoplasmic reticulum (ER) (Berridge 2002). The ER forms a continuous, intracellular network, allowing it to regulate both local and global $\mathrm{Ca}^{2+}$ signals. As in other neurons, the ER network in SNc DA neurons extends throughout the somatodendritic tree (Schwyn and Fox 1974; Mogami et al. 1997; Park et al. 2000; Choi et al. 2006). Highaffinity ATP-dependent transporters move $\mathrm{Ca}^{2+}$ from the cytoplasm into the ER lumen. The absence of high-affinity, anchored intraluminal $\mathrm{Ca}^{2+}$ buffers and the physical continuity of the lumen within the cell (Mogami et al. 1997; Park et al. 2000) allows the ER to rapidly $(\sim 30 \mu \mathrm{m} / \mathrm{s})$ redistribute $\mathrm{Ca}^{2+}$ between intracellular compartments. $\mathrm{Ca}^{2+}$ sequestered in the ER is released at sites where it can be pumped back across the plasma membrane or where it can be used to modulate cellular function (Rose and Konnerth 2001; Cui et al. 2004; Verkhratsky 2005; Bardo et al. 2006; Park et al. 2008).

Mitochondria partner with the ER in $\mathrm{Ca}^{2+}$ homeostasis. Mitochondrial motility is controlled in such a way as to bring them close to sites of $\mathrm{Ca}^{2+}$ release (Boldogh and Pon 2007; Chen and Chang 2009). Mitochondria also are commonly found physically coupled to the ER by mitochondria-associated membrane (MAM) (Pizzo and Pozzan 2007; Hayashi et al. 2009). These regions of juxtaposition create multifunctional signaling microdomains (Csordas et al. 2006; Rizzuto and Pozzan 2006; de Brito and Scorrano 2008; Hayashi et al. 2009). For example, within these microdomains, $\mathrm{Ca}^{2+}$ released by the ER through ryanodine (RyR) and inositol trisphosphate (IP3) receptors moves down the steep potential gradient $(\sim-200 \mathrm{mV})$ across the inner mitochondrial membrane into the matrix, through a pore called the mitochondrial $\mathrm{Ca}^{2+}$ uniporter (MCU) (Kirichok et al. 2004). The MCU has recently been cloned, opening an important door for detailed study of its role and regulation (De Stefani et al. 2011).

Although MAMs create a means by which mitochondria can assist the ER in $\mathrm{Ca}^{2+}$ buffering, it seems highly likely that these junctions serve another signaling function that is independent of buffering per se. One well-documented 
D.J. Surmeier et al.

function of $\mathrm{Ca}^{2+}$ flux through the MCU is stimulation of the tricarboxylic acid (TCA) cycle enzymes that produce reducing equivalents for oxidative phosphorylation (OXPHOS) (McCormack et al. 1990). In muscle, $\mathrm{Ca}^{2+}$ efflux from the ER stimulates contraction, which results in ATP hydrolysis, and in parallel stimulates mitochondrial OXPHOS, thereby helping to meet this metabolic demand (Jouaville et al. 1999). For this system to work effectively in neurons, the $\mathrm{Ca}^{2+}$ signal reaching mitochondria should accurately reflect metabolic needs associated with excitability. Recent work (Cardenas et al. 2010) shows that in neurons this system plays an essential role in regulating mitochondrial metabolism. However, because superoxide production is elevated by stimulation of the electron transport chain in the absence of sufficient ADP to drive the proton current through complex V (Korshunov et al. 1997), this system could have deleterious consequences if the "demand" on ATP does not meet the "supply" provided by $\mathrm{Ca}^{2+}$-mediated acceleration of the TCA cycle. Interestingly, Foskett's group has shown that elevated IP3R-mediated release of ER $\mathrm{Ca}^{2+}$ significantly increases the production of ROS by mitochondria (Muller et al. 2011). ER-stimulated production of mitochondrial ROS production could prove to be the driving force in PD pathogenesis (see below).

\section{NEURONAL PACEMAKING POSES A SPECIAL CHALLENGE TO IONIC HOMEOSTASIS}

In most neurons, the challenge to ionic homeostasis created by spiking is episodic. Striatal spiny projection neurons, for example, reside very near the $\mathrm{K}^{+}$equilibrium potential some $40 \mathrm{mV}$ away from spike threshold in the absence of synaptic potentials (Gerfen and Surmeier 2011). Excitatory synaptic input drives the membrane potential to spike threshold for hundreds of milliseconds at a time, but this activity is intermittent.

There is a subset of neurons in the brain that cannot stay quiet, spiking frequently and autonomously; that is, in the absence of synaptic input they spike on their own. Typically, autonomously generated spiking is very regular (syn- aptic input decreases this regularity); as a consequence, these neurons are often referred to as autonomous pacemakers. Autonomous pacemakers can be divided into fast and slow spiking classes. Fast autonomous pacemakers, such as globus pallidus or substantia nigra pars reticulata ( $\mathrm{SNr}$ ) GABAergic neurons, spike at rates above $20 \mathrm{~Hz}$. At physiological temperature (Atherton and Bevan 2005; Chan et al. 2011) these neurons have very brief action potentials $(<1 \mathrm{~ms})$ and robustly express $\mathrm{Ca}^{2+}$-binding proteins (Lee and Tepper 2007; Gross et al. 2011). Typically, autonomous spiking in these cells is driven by a combination of monovalent cation channels, such as $\mathrm{Na}_{\mathrm{v}} 1 \mathrm{Na}^{+}$and hyperpolarization and nucleotide-activated cation (HCN) channels (Chan et al. 2004; Mercer et al. 2007). Slow pacemakers spike at much lower frequencies $(\sim 2-5 \mathrm{~Hz})$ and have broad spikes $(>2 \mathrm{~ms})$. Neurons of this class are found scattered in many regions of the brain, including the hypothalamus, striatum, mesencephalon, and medulla (Paladini et al. 2007; Ding et al. 2010; Guzman et al. 2010). Although there has been much less work on pacemaking mechanisms in this class of neuron, it has been shown that their pacemaking typically depends on $\mathrm{Na}_{\mathrm{v}} 1$, HCN channels, as well as cationic leak channels (Bean 2007). In a subset of these neurons, voltage-dependent L-type $\mathrm{Ca}^{2+}$ channels contribute to the inward current that drives pacemaking (Puopolo et al. 2007; Guzman et al. 2009; Putzier et al. 2009). These L-type channels have a distinctive pore-forming subunit $\left(\mathrm{Ca}_{\mathrm{v}} 1.3\right)$ that is coded for by the CACNA1D gene (Chan et al. 2007), which confers on the channel the ability to open at relatively negative membrane potentials (Surmeier et al. 2010). These channels are relatively rare and most L-type channels found in the brain have a $\mathrm{Ca}_{\mathrm{v}} 1.2$ pore-forming subunit (coded for by the CACNA1C gene) (SinneggerBrauns et al. 2009); this means that in most neurons, L-type channels open only during periods of strong depolarization, like during a spike.

Although it has not been directly measured, sustained pacemaking must come with a significant metabolic price tag. In these neurons, the ionic gradients underlying excitability are under 
constant assault. This should be particularly true in slow pacemakers with broad action potentials that use $\mathrm{Ca}^{2+}$ channels to help push the plasma membrane toward spike threshold. As noted above, $\mathrm{Ca}^{2+}$ must be pumped across the plasma membrane against a very steep potential gradient. The high-affinity, low-capacity PMCA appears to require one molecule of ATP for every $\mathrm{Ca}^{2+}$ ion moved across the plasma membrane. Moreover, in cells of this class that lack significant expression of fixed $\mathrm{Ca}^{2+}$-buffering proteins (such as SNc DA neurons), $\mathrm{Ca}^{2+}$ entering neurons most likely is pumped not only by the proteins in the plasma membrane but also by those of intracellular organelles (such as the ER), adding to their metabolic burden.

\section{NEURONS CARRY OTHER METABOLIC WEIGHTS}

Although maintaining the ionic gradients underlying excitability undoubtedly creates a metabolic burden, this is not the only one neurons must carry. Synaptic transmission poses a burden. There are two aspects of this process that should be considered. Neurons communicate with one another largely (not exclusively) by release of transmitter molecules. These transmitters act at either ionotropic or metabotropic receptors. Ionotropic receptors change the membrane potential of postsynaptic neurons by opening a pore that allows ions to flow down their electrochemical gradients. With the termination of synaptic transmission, the pore closes. Although the ionic fluxes produced by a single synaptic event are much smaller than those produced by a spike, they still dissipate the ionic gradients established by pumps/exchangers and therefore consume ATP. Glutamatergic synaptic transmission, which engages receptors that are permeable to $\mathrm{Na}^{+}$and $\mathrm{Ca}^{2+}$ ions, can create a significant metabolic burden on neurons, particularly in pathological conditions (Nicholls et al. 2007). The energetic demands posed by metabotropic receptors are more difficult to gauge, as they rarely directly couple to ion channel gating.

Synaptic transmission poses an energetic burden for the presynaptic neuron as well.
Physiological Phenotype in Parkinson's Disease

Establishing the high transmitter concentration gradient across the vesicular membrane needed for effective synaptic function requires ATP (McMahon and Nicholls 1991). In the case of monoaminergic neurons, maintaining cytosolic transmitter concentration at low levels also is important to prevent its oxidation and the generation of reactive quinones (Sulzer and Zecca 2000; Greenamyre and Hastings 2004). The exocytosis process is itself ATP dependent. It is surprising that the combination of a reactive transmitter (dopamine) and the demands of exocytosis seem not to create a significant oxidative stress on DA terminal (Choi et al. 2011). Synapses also are typically at great distance from the nucleus and principal protein synthesis machinery, requiring ATP-dependent axonal transport of proteins, vesicles, and mitochondria. Synaptic protein lifetimes appear to be, in general, short, adding to the burden of maintaining them. The metabolic load accompanying a few dozen synapses seems not to pose a significant problem for most neurons. However, some neurons, such as SNc DA neurons, maintain as many as several hundred thousand synapses (Matsuda et al. 2009), potentially creating a sustained and significant metabolic bill.

\section{NEURONS DEPEND ON MITOCHONDRIA}

Because of their high basal energy demand, neurons depend on mitochondria to supply the ATP necessary for survival. Under normal conditions, glucose is metabolized by neurons to produce ATP. Glycolysis itself results in the generation of $2 \mathrm{~mol}$ of ATP per mole of glucose converted to pyruvate. However, when the pyruvate is transported into the mitochondria and further oxidized by the TCA cycle and the electron transport chain, the total yield of ATP increases to $36 \mathrm{~mol}$ per mole of glucose. The dependence of a cell on mitochondrial oxidative phosphorylation can be evaluated by creating genetic knockout models involving deletion of genes that are required for mitochondrial function. Mitochondria contain DNA that encodes a set of proteins that are required for electron transport chain function; these genes are transcribed and translated in the mitochondrial 
D.J. Surmeier et al.

matrix. The mitochondrial transcription factor TFAM is required for that process, and deletion of TFAM abolishes mitochondrial transcription and undermines the stability of mitochondrial DNA. Accordingly, deletion of TFAM in a cell leads to loss of mitochondrial DNA and the development of a progressive decline in mitochondrial ATP production, even though the mitochondrial mass may be increased. The deletion of TFAM in specific cell lineages of the mouse reveals that some cells survive and function normally without functional mitochondria, whereas other cells fare poorly. For example, in epidermal progenitor cells the loss of TFAM has no apparent effect on proliferation or differentiation responses (Baris et al. 2011). In contrast, deletion of TFAM in the mouse heart leads to a progressive cardiomyopathy associated with the loss in ATP production and eventual lethality (Hansson et al. 2004). Likewise, deletion of TFAM leads to neuronal loss. For example, deletion of TFAM in SNc DA neurons leads to respiratory chain deficiency, cell loss, and impaired motor function (Ekstrand et al. 2007). This observation is consistent with a large literature demonstrating that mitochondrial toxins taken up by dopaminergic neurons lead to their demise (Przedborski and Vila 2003; Przedborski et al. 2004).

During intermediary metabolism, reducing equivalents in the form of nicotinamide adenine dinucleotide (NADH), nicotinamide adenine dinucleotide phosphate (NADPH), and FADH2 are obtained from the oxidation of metabolic substrates. The mitochondrial electron transport chain transfers these reducing equivalents ultimately to molecular $\mathrm{O}_{2}$. The free energy change associated with the transfer of electrons down the chain is used to translocate protons from the matrix to the intermembrane space, generating an electrochemical gradient across the inner membrane (typically $-180 \mathrm{mV})$. Proton translocation occurs at complexes I, III, and IV and the electrons are ultimately transferred to $\mathrm{O}_{2}$ at the terminal cytochrome oxidase (complex IV). The transmembrane gradient is used by the FoF1-ATP synthase (complex V) to generate ATP from $\mathrm{ADP}$ and inorganic phosphate $(\mathrm{Pi})$. Hence, the dynamic regulation of the mitochondrial transmembrane potential $\left(\Delta \Psi_{\mathrm{m}}\right)$ is determined by the balance between the rate of electron transport and proton translocation (tending to augment the potential) and the rate of ATP synthesis (tending to dissipate it). Some additional dissipation of the potential occurs through the activity of coupled membrane transport systems, uncoupling proteins, or nonspecific membrane leaks.

\section{MITOCHONDRIA AND OXIDANT STRESS}

For more than 40 years it has been known that mitochondria can potentially generate reactive oxygen species (ROS) (Jensen 1966b). The transfer of four electrons to $\mathrm{O}_{2}$ at complex IV yields $\mathrm{H}_{2} \mathrm{O}$, but a small percentage of the electrons are captured by $\mathrm{O}_{2}$ at proximal sites in the chain. The transfer of a single electron to $\mathrm{O}_{2}$ yields superoxide anion, a free radical. Sites implicated in that process include complexes I, II, III, and possibly certain dehydrogenases of the TCA cycle (Murphy 2009). These radicals are released into the matrix compartment where they can potentially interact with lipids, proteins, DNA, or with each other.

The factors regulating the generation of superoxide from the electron transport chain are not fully understood. Some observations suggest that mitochondrial membrane hyperpolarization can augment ROS generation. In complex I, reducing equivalents obtained from $\mathrm{NADH}$ are transferred to ubiquinone-generating ubiquinol, a membrane-soluble electron carrier that delivers a pair of electrons to complex III. Complex II links the TCA cycle to the electron transport chain by oxidizing succinate to fumarate, delivering the electrons to complex III via ubiquinol. In isolated mitochondria given succinate to supply electrons into complex II in the absence of ADP, the membrane potential increases. Complex I is reversible and under hyperpolarized conditions a retrograde electron flux occurs from ubiquinol to NADH. This phenomenon is associated with a large increase in ROS production from complex I (Votyakova and Reynolds 2001). It can be inhibited by rotenone, a drug that inhibits reverse electron transport into the 
distal end of complex I. It can also be inhibited by modest decreases in membrane potential, as the reverse flux is only favored when the membrane is highly polarized. Although this mechanism has been cited as an important source of ROS generation by isolated mitochondria, its significance under physiological conditions is questionable because the conditions that promote it (high membrane potential, succinate energy supply, lack of ADP) rarely occur in the intact cell.

Other mechanisms of ROS production in the mitochondrial matrix may relate to the rate of electron flux, with high rates of activity correlating with increased ROS generation. In that regard, the stimulation of mitochondrial activity by high ADP production in the cell would increase the transfer of electrons down the chain, potentially increasing the likelihood that some electrons will be captured by $\mathrm{O}_{2}$ before they reach cytochrome oxidase (Lee et al. 2001; Rigoulet et al. 2011). The generation of superoxide in the matrix is also enhanced in cells subjected to hyperoxic conditions, where an increased availability of $\mathrm{O}_{2}$ in the matrix compartment can enhance the probability that it will capture an electron from the electron transport chain. Finally, genetic defects in the expression or structure of various electron transport complex subunits can enhance the generation of superoxide. For example, in humans who are heterozygous for the $\mathrm{B}, \mathrm{C}$, or $\mathrm{D}$ subunits of succinate dehydrogenase (complex II), some cells can undergo somatic cell loss of heterozygosity, leading to the deletion of that subunit from the cell (Baysal et al. 2000). The A subunit of complex II contains the succinate dehydrogenase activity, whereas the B-D subunits are responsible for transferring the electrons to ubiquinone. If the $\mathrm{B}, \mathrm{C}$, or D subunit is disrupted while the A subunit is still expressed, the electrons derived from succinate oxidation cannot enter the electron transport chain and become stranded on the flavin group. This condition enhances the nonspecific generation of superoxide, which appears to enhance the tendency to form tumors (Guzy et al. 2008). The complete loss of complex II function in a cell leads to an inhibition of electron transport cou-
Physiological Phenotype in Parkinson's Disease

pled to proton extrusion, and thus a loss of OXPHOS. Survival of the cell then depends entirely on ATP production by glycolysis, resulting in the release of lactic acid. Ironically, in that state the mitochondria shift to become consumers of ATP, which is taken up from the cytosol and used to maintain the mitochondrial membrane potential through reverse operation of complex V.

To protect against the potential detrimental effects of matrix oxidant stress, a complex set of "antioxidant" systems are expressed in the mitochondria that act to degrade ROS. Manganese superoxide dismutates (MnSOD) is a nuclearencoded gene that is transcribed on cytosolic ribosomes and then imported into the mitochondrial matrix where it acts to dismute a pair of superoxide anions into hydrogen peroxide $\left(\mathrm{H}_{2} \mathrm{O}_{2}\right) \cdot \mathrm{H}_{2} \mathrm{O}_{2}$ is subsequently degraded by glutathione peroxidase and peroxiredoxins III and $\mathrm{V}$, which are also expressed in the matrix. A distinct pool of reduced glutathione (GSH) resides in the mitochondria and is used by the reductase systems to clear $\mathrm{H}_{2} \mathrm{O}_{2}$ and lipid hydroperoxides. The resulting oxidized glutathione (GSSG) is subsequently re-reduced to GSH by glutathione reductase, which uses NADPH. The resulting $\mathrm{NADP}^{+}$is then re-reduced to NADPH by dehydrogenases in the TCA cycle, such as isocitrate dehydrogenase-2. Ideally, under physiological conditions the rate of superoxide production is balanced by the rate of clearance, preventing the accumulation of superoxide $/ \mathrm{H}_{2} \mathrm{O}_{2}$, thereby protecting the mitochondria from the damaging effects of oxidants.

\section{MITOCHONDRIAL HYPOTHESIS OF AGING}

In the 1920s, Pearl (1928) noted a correlation between the metabolic rate of an organism and its lifespan, such that animals with lower basal rates of metabolism lived longer than those with higher rates. This idea became known as the "rate of living theory of aging" (Pearl 1928) that linked metabolic rates to lifespan. In 1954, Commoner and coworkers (1954) reported detection of oxygen free radical formation in cells, using a paramagnetic resonance absorption technique. The idea that cells can generate 
D.J. Surmeier et al.

oxygen radicals led Harman (1956) to hypothesize that aging and degenerative diseases may be attributable to the damaging effects of free radicals on cellular contents and extracellular connective tissue. According to that theory, interventions that lessen the generation or enhance the detoxification of reactive oxygen molecules in an organism should lessen the manifestations of aging and enhance longevity. This "oxygen radical theory of aging" evolved into the "mitochondrial theory of aging" after it was recognized that the mitochondrial electron transport chain is an important source of superoxide generation in the cell (Jensen 1966a).

Although mitochondria possess a sophisticated system for detoxifying reactive oxygen species, some of the ROS may survive long enough to react with lipids, proteins, or DNA. The probability of sustaining oxidant-mediated damage increases when the rate of ROS generation accelerates in response to stress, disease, or in mitochondria that become dysfunctional or damaged with aging. ROS interaction with mitochondrial complexes can lead to damage and/or dysfunction, and in some cases this damage can augment ROS production at that site or at other sites located earlier in the chain. One target of oxidative damage is mitochondrial DNA (mtDNA), which encodes a set of essential subunits of the electron transport chain as well as the mitochondrial transfer RNAs (tRNAs) required for translation. ROS-mediated damage to mtDNA is hypothesized to be an important mechanism underlying mutation in the mitochondrial genome (Beckman and Ames 1998). In that regard, ROS-mediated damage to mtDNA may lead to the expression of mutant forms of the electron transport complexes, whose altered function leads to an augmentation of their ROS production. This "vicious cycle" further injures the mtDNA and other mitochondrial constituents, thus amplifying the dysfunction and ROS generation (Wallace 2010). Indeed, multiple observations support the idea that mtDNA mutations contribute to the aging process (Aguilaniu et al. 2005). Furthermore, a large body of work has linked the level of mitochondrial oxidant stress to the aging phenotype and organismal lifespan, using genetic overexpression, knockdown or knockout of antioxidant enzymes in widely diverse species (Jang and Remmen 2009).

Although the "mitochondrial theory of aging" is appealing in its simplicity and teleology, findings from other studies appear to challenge that model. First, mice that are heterozygous for the mitochondrial superoxide dismutase (MnSOD) show a 50\% decrease in antioxidant capacity and evidence of increased mtDNA damage, yet they fail to show a significant decrease in lifespan compared with wild-type mice (Van Remmen et al. 2003). Conversely, increases in MnSOD activity induced in a transgenic line by overexpression of MnSOD were associated with decreased evidence of lipid peroxidation and decreased age-related decline in ATP production, yet no change in lifespan or age-related pathology (Jang et al. 2009). In other studies, Schriner et al. (2005) generated transgenic mice with mitochondria-targeted expression of catalase and observed an increase in median and maximal lifespan of $\sim 20 \%$, in association with a decrease in the frequency of mitochondrial deletions in skeletal muscle. However, when backcrossed into the C57BL6 background this phenotype was diminished whereas the mitochondrial catalase expression was retained. Thioredoxin-2 $(\operatorname{Tr} x 2)$ is a thiol reductase expressed in the mitochondria along with its partner, thioredoxin-2 reductase (Holmgren and Sengupta 2010). Genetic deletion of $\operatorname{Tr} x 2\left(\operatorname{Tr} x 2^{-/-}\right)$leads to embryonic lethality, indicating the importance of this system for maintaining mitochondrial protein thiol redox balance. Heterozygous animals $\left(\operatorname{Tr} \times 2^{+/-}\right)$survive and show the expected evidence of increased mitochondrial oxidative stress and dysfunction (Perez et al. 2008) yet these mice do not show any evidence of shortened lifespan (Perez et al. 2009). Interestingly, overexpression of thioredoxin 1, which is expressed in the cytosol, enhances survival in the earlier stages of life, but does not extend maximum lifespan in the C57BL6 genetic background (Perez et al. 2011). In comparing multiple genetic models affecting oxidant stress, Richardson and colleagues (Perez et al. 2009) found that only $\mathrm{Cu}, \mathrm{Zn}-\mathrm{SOD}$ deletion had an effect on lifespan, leading them to question 
whether the oxidative stress theory of aging is dead.

Using an elegant approach to disrupt mitochondrial DNA integrity, Trifunovic et al. (2004) and Kujoth et al. (2005) generated mouse lines with a knockin of a mutant version of the mitochondrial DNA polymerase POLG. The knockin carries a point mutation within the catalytic region responsible for proofreading mtDNA, leading to disruption of that function. Mice homozygous for this mutation accumulate mtDNA mutations over time and experience a significant shortening of lifespan compared with wild-type mice in the same background. These "mutator mice" also show an aging phenotype that is reminiscent of the pattern seen in aging humans. However, mitochondrial ROS generation and the level of lipid peroxidation and DNA oxidation was not increased in comparison to wild-type animals, raising questions about the theory that defects in mtDNA will lead to the generation of additional ROS by the electron transport chain. Studies of mtDNA in the heterozygous POLG mutant mice reveal significant increases in mtDNA point mutations compared with wildtype mice, yet those mice do not show a shortened lifespan or phenotypic evidence of advanced aging (Vermulst et al. 2007). However, the homozygous mice do have shortened lifespans; this group advanced the idea that there was a threshold for mtDNA deletions (arising from point mutations) that led to accelerated aging.

These observations highlight the controversy regarding the relationships among mitochondrial oxidant stress, the integrity of mtDNA, and the regulation of lifespan in diverse species. Although further work is needed to clarify the +apparent discrepancies in this field, these studies do provide some insight into the processes that may regulate the demise of DA neurons in SNc of patients with PD. First, it is important to note the strong association between aging and the development of PD, suggesting that SNc DA neurons may age more rapidly than other cell types in the brain. In view of the above controversy, it seems likely that the genes and processes regulating longevity of the organism may be distinct from those that regulate the aging phenotype in specific cell types. In that regard it is conceivable that some cells, by virtue of their phenotype and function, may be uniquely sensitive to genetic or environmental factors that can threaten their long-term survival. Those features may explain the relationship between PD and aging, yet have no mechanistic connection to the genetic factors regulating longevity.

\section{PHYSIOLOGICAL FEATURES OF NEURONS AT HIGH RISK IN PD}

Although PD is a disease of neurons, not all neurons are affected in PD (Braak et al. 2003). The vast majority of the neurons in the brain show no signs of pathology, even in the late stages of the disease. What then distinguishes neurons at risk in PD?

\section{What Makes SNc DA Neurons Vulnerable in PD?}

The neurons with the best-documented vulnerability are SNc DA neurons. The cardinal motor symptoms of PD, including bradykinesia, rigidity, and resting tremor, are the first to appear clinically and are clearly linked to the degeneration and death of SNc DA neurons (Hornykiewicz 1966). The efficacy of the clinical goldstandard treatment of L-dopa, a DA precursor, is testament to the centrality of DA neurons in the motor symptoms of PD. Why do these neurons die? A widely held theory implicates DA itself in their death, suggesting that oxidation of cytosolic DA (and its metabolites) leads to the production of cytotoxic free radicals (Greenamyre and Hastings 2004). However, there are reasons to doubt whether this type of cellular stress alone is responsible for the loss of DA neurons in PD. For example, there is considerable regional variability in the vulnerability of DA neurons in PD, with some areas being devoid of pathological markers (Matzuk and Saper 1985; Kish et al. 1988; Saper et al. 1991; Ito et al. 1992; Damier et al. 1999). Moreover, Ldopa administration (which relieves symptoms by elevating DA levels in PD patients) does not 
D.J. Surmeier et al.

accelerate disease progression (Fahn 2005), suggesting that DA itself is not a significant source of reactive oxidative stress, at least in the short term. Sulzer and colleagues have recently reported that $\mathrm{Ca}^{2+}$ entry through L-type channels stimulates DA metabolism in SNc DA neurons, pushing cytosolic DA concentrations into a toxic range with L-dopa loading (Mosharov et al. 2009). However, taken together the available data does not argue that DA itself is likely to be the principal culprit in the disease.

What is distinctive about $\mathrm{SNc}$ DA neurons is their physiological phenotype. Adult SNc DA neurons are slow, broad spike, autonomous pacemakers lacking much intrinsic $\mathrm{Ca}^{2+}$ buffering capacity (Foehring et al. 2009). This pacemaking activity is believed to be important in maintaining ambient DA levels in regions that are innervated by these neurons, particularly the striatum (Romo and Schultz 1990). Although most neurons rely exclusively on monovalent cation channels to drive pacemaking, $\mathrm{SNc}$ DA neurons also engage ion channels that allow extracellular $\mathrm{Ca}^{2+}$ to enter the cytoplasm (Ping and Shepard 1996; Bonci et al. 1998; Puopolo et al. 2007) leading to elevated intracellular $\mathrm{Ca}^{2+}$ concentrations (Wilson and Callaway 2000; Chan et al. 2007).

In adult $\mathrm{SNc}$ dopaminergic neurons, the currents that flow through these channels are of sufficient magnitude to sustain a membrane potential oscillation when voltage-dependent $\mathrm{Na}^{+}$channels are blocked with tetrodotoxin (Fig. 3) (Guzman et al. 2009). This oscillation also depends on small conductance $\mathrm{Ca}^{2+}$-activated $\mathrm{K}^{+}$(SK) channels (Ping and Shepard 1996, 1999). The presence of this slow oscillatory potential and the sensitivity of pacemaking to dihydropyridines (DHP) led to the conjecture that L-type channels were necessary for pacemaking in SNc DA neurons (Nedergaard et al. 1993; Chan et al. 2007; Puopolo et al. 2007). However, the concentrations of DHP antagonist required to stop pacemaking was three orders of magnitude above the equilibrium binding constant for $\mathrm{Ca}_{\mathrm{v}} 1$ channels, raising questions about the specificity of drug action (Surmeier et al. 2010). What made these experiments difficult to interpret was that DHPs are not channel blockers (they do not plug the pore), but rather are negative allosteric regulators or antagonists (Sinnegger-Brauns et al. 2009). Furthermore, the allosteric interaction of DHPs with the channel is the voltage dependent. The equilibrium binding data was taken from membrane preparations where the transmembrane potential was nominally zero $\mathrm{mV}$, maximizing affinity. At more negative membrane potentials, the affinity of the DHPs for L-type channels falls. However, the membrane potential of $\mathrm{SNc}$ DA neurons is always in a range near that needed to maximize binding affinity because of their pacemaking phenotype. We have modeled the interaction between DHP binding and pacemaking using the modulated receptor assumption advanced by Bean (1984); these simulations clearly suggest that submicromolar DHP concentrations should result in near complete antagonism (Surmeier et al. 2010; Ilijic et al. 2011). Using two-photon laser scanning microscopy in brain slices, this model was tested by monitoring dendritic $\mathrm{Ca}^{2+}$ fluxes in SNc DA neurons, which are attributable to Ltype channels, during pacemaking (Guzman et al. 2009); these studies showed that submicromolar concentrations of the DHP isradipine eliminated any detectable fluctuation in distal dendritic $\mathrm{Ca}^{2+}$ concentration without altering pacemaking frequency, providing a strong confirmation of the hypothesis that $\mathrm{Ca}_{\mathrm{v}} 1.3$ channels are not necessary for pacemaking. Simulations of pacemaking have shown how this might happen (Guzman et al. 2009); in the model, as inward current through $\mathrm{Ca}_{\mathrm{v}} 1.3$ channels falls, outward current through SK $\mathrm{K}^{+}$channels falls in parallel, leading to essentially no change in net transmembrane current and the maintenance of pacemaking. That said, in the absence of $\mathrm{Ca}_{\mathrm{v}} 1.3$ channels, pacemaking becomes less robust and stops with partial antagonism of HCN channels; adult SNc DA neurons with intact $\mathrm{Ca}_{\mathrm{v}} 1.3$ channels are resistant to this manipulation (Chan et al. 2007; Guzman et al. 2009).

Ventral tegmental area (VTA) DA neurons, which also are slow pacemakers, diverge from SNc DA neurons in two potentially important respects of relevance to this discussion. First, the $\mathrm{Ca}_{\mathrm{v}} 1.3 \mathrm{Ca}^{2+}$ channel density is dramatically 
Control

A

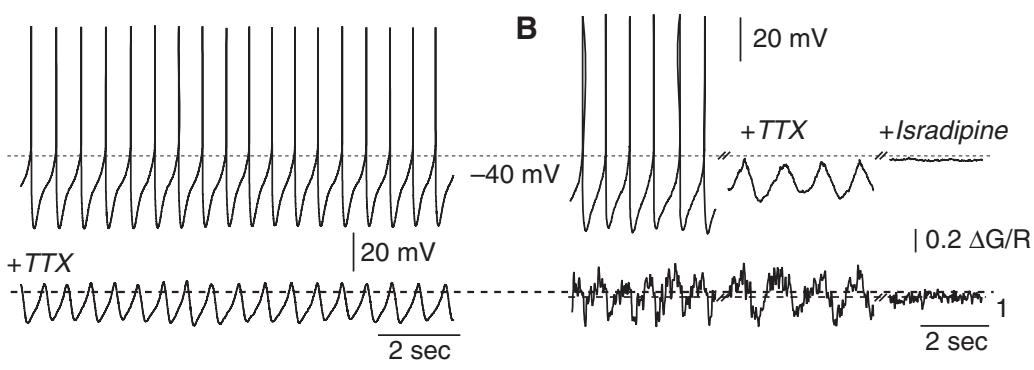

C

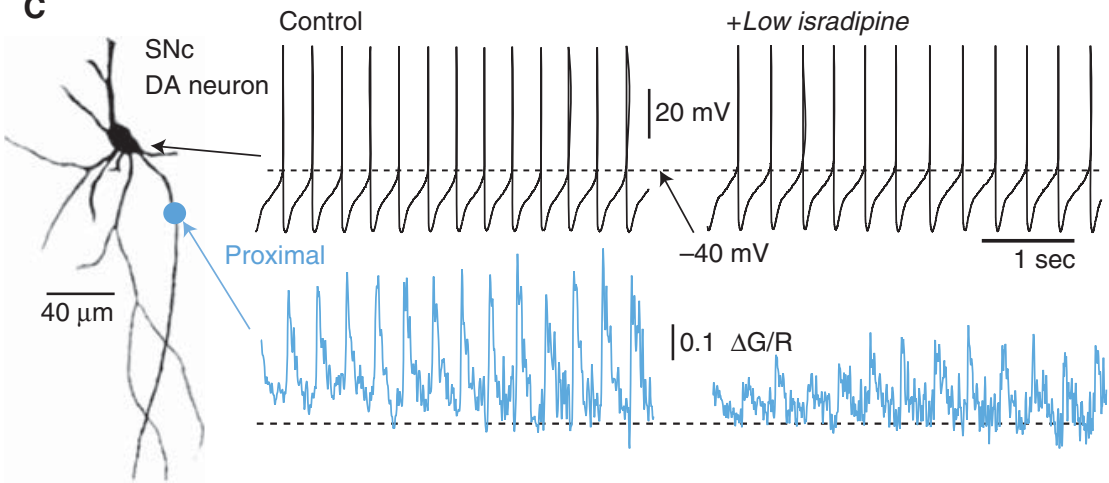

D

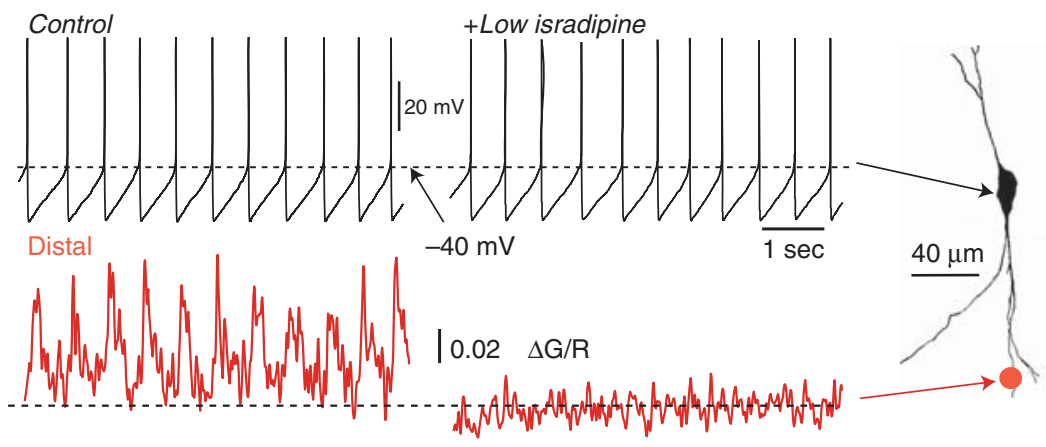

Figure 3. $\mathrm{Ca}_{\mathrm{v}} 1.3 \mathrm{~L}$-type $\mathrm{Ca}^{2+}$ channels contribute to the excitability of SNc DA neurons. (A) Pacemaking firing of $\mathrm{SNc}$ DA neurons recorded in current-clamp whole cell configuration in mouse midbrain slices. Pharmacological blockade of sodium channels with tetrodotoxin (TTX) leaves an ongoing membrane potential oscillation. $(B)$ Another example of SNc DA neuron in pacemaking mode synchronized to dendritic $\mathrm{Ca}^{2+}$ oscillations imaged from a distal dendrite using Fluo4 $\mathrm{Ca}^{2+}$ indicator. Following application of TTX, the membrane potential oscillation is associated with an ongoing $\mathrm{Ca}^{2+}$ oscillation attenuated following antagonism of the DHP-sensitive L-type channels with isradipine. $(C)$ Representative pacemaking SNc DA neuron displaying $\mathrm{Ca}^{2+}$ transients from a proximal dendrite ( $\sim 30 \mu \mathrm{m}$ away from the soma, blue trace), and following bath application of isradipine to block L-type channels. $(D)$ The same as part $C$, with the difference that $\mathrm{Ca}^{2+}$ imaging was performed on a distal dendrite ( $\sim 80 \mu \mathrm{m}$ away from the soma, red trace). Antagonism of L-type channels attenuates the underlying $\mathrm{Ca}^{2+}$ oscillation in distal dendrites, while in a proximal dendrite; there is a residual $\mathrm{Ca}^{2+}$ transient that might be dependent on other voltage-gated $\mathrm{Ca}^{2+}$ channels. These results can suggest a potential gradient of L-type channel expression that increases as you move farther away from the soma. Parts $C$ and $D$ also show that isradipine did not affect pacemaking automaticity, suggesting that $\mathrm{Ca}^{2+}$ influx through L-type channels can be attenuated without affecting the pacemaking firing of SNc DA neurons. (Data used in this figure have been adapted from Chan et al. 2007 and Guzman et al. 2010, with permission from the authors.) 
D.J. Surmeier et al.

lower than in SNc DA neurons (Chan et al. 2007; Guzman et al. 2010). Second, the expression of the $\mathrm{Ca}^{2+}$-buffering protein calbindin is much higher in VTA DA neurons than it is in SNc DA neurons (German et al. 1992a). The combination of these two factors results in the absence of detectable oscillations in dendritic $\mathrm{Ca}^{2+}$ concentration during pacemaking in VTA DA neurons. This should also lower the metabolic load on these neurons (Guzman et al. 2010). The human homologs of these VTA neurons have a significantly lower risk of degeneration in PD (Kish et al. 1988; German et al. 1992a; Pignatelli et al. 2005; Belzunegui et al. 2007), linking metabolism to risk in PD at a different point in the metabolic spectrum. There are many unanswered questions, though, about how these physiological features are linked to risk. How, for example, do $\mathrm{Ca}^{2+}$-buffering proteins shape the metabolic burden of $\mathrm{Ca}^{2+}$ influx? Based on experiments examining intrinsic $\mathrm{Ca}^{2+}$-buffering capacity using whole cell patch pipettes, it appears that most intrinsic $\mathrm{Ca}^{2+}$-buffering proteins are immobile, as they are not washed out by dialysis (Augustine et al. 2003). By binding $\mathrm{Ca}^{2+}$, these proteins "sequester" it away from signaling proteins and organelles during opening of membrane channels. When these channels close and cytosolic $\mathrm{Ca}^{2+}$ levels begin to decrease with activity of the pumps/exchangers, $\mathrm{Ca}^{2+}$ could move from this bound pool to become available for transport out of the cell. Because the interaction between $\mathrm{Ca}^{2+}$ and the binding proteins is ionic and does not involve ATP-dependent sequestration into an organelle, this could be an energetically "cheap" way for the cell to manage $\mathrm{Ca}^{2+}$ influx.

Recent work by our group has shown that maintained opening of L-type $\mathrm{Ca}^{2+}$ channels in $\mathrm{SNc}$ DA neurons creates a basal mitochondrial oxidant stress (Guzman et al. 2010). Recall that these neurons lack abundant $\mathrm{Ca}^{2+}$-buffering proteins (Foehring et al. 2009). These studies used a transgenic mouse that expressed a mitochondrially targeted redox-sensitive variant of green-fluorescent protein (mito-roGFP) (Hanson et al. 2004; Guzman et al. 2010) expressed under control of the tyrosine hydroxylase $(\mathrm{TH})$ promoter (Fig. 3). The use of roGFP allowed mitochondrial matrix redox state to be quantitatively estimated, something not possible with conventional redox probes. Using two-photon laser scanning microscopy to monitor mitoroGFP in brain slices from young adult mice, we found that the engagement of plasma membrane $\mathrm{Ca}_{\mathrm{v}} 1.3 \mathrm{~L}$-type $\mathrm{Ca}^{2+}$ channels during normal autonomous pacemaking created an oxidant stress in the mitochondria that was specific to the vulnerable SNc DA neurons and not apparent in neighboring VTA DA neurons. The oxidant stress engaged defenses that induced transient, mild mitochondrial depolarization or uncoupling. The mild uncoupling was not affected by deletion of cyclophilin $\mathrm{D}$, which is a component of the permeability transition pore, but was attenuated by genipin and purine nucleotides, which are antagonists of cloned uncoupling proteins. Knocking out DJ-1 (also known as PARK7 in humans and Park7 in mice), which is a gene associated with an early-onset form of $\mathrm{PD}$, down-regulated the expression of two uncoupling proteins (UCP4 [SLC25A27] and UCP5 [SLC25A14]), compromised $\mathrm{Ca}^{2+}$-induced uncoupling, and increased oxidation of matrix proteins specifically in $\mathrm{SNc}$ dopaminergic neurons. The results with the DJ1 knockout-showing that the impact of DJ-1 deletion depends on a physiological phenotype that engages mitochondrial oxidant defensesprovides an example of how mutations in a widely expressed gene can affect a select subpopulation of neurons. That said, the mechanisms governing mitochondrial matrix redox state are complex and the hypothesis that UCP4/5 contribute to this regulation must be rigorously tested; the most obvious strategy would be to knock the mRNA coding for these proteins down using viral delivery of small interfering RNAs (siRNAs).

The metabolic demands posed by maintaining transmembrane ionic gradients underlying excitability led Nicholls (2002) to postulate that neurons are at risk in neurodegenerative disease because they have a modest bioenergetic or respiratory reserve. This reserve is defined as the difference between the maximum capacity for ATP generation by oxidative phosphorylation and the basal consumption of ATP. The smaller 
this respiratory reserve, the more likely episodic demands on metabolism, such as exposure to a toxin or bursts of spiking, the more likely cellular ATP levels will decrease and create a bioenergetics crisis, leading to loss of membrane potential or other ATP-dependent processes. Persistent loss of membrane potential will lead to massive $\mathrm{Ca}^{2+}$ influx and cell death (Beal 1995; Choi et al. 2011). Clearly, slow pacemaking neurons with broad action potentials, sustained $\mathrm{Ca}^{2+}$ influx, and low intrinsic $\mathrm{Ca}^{2+}$ buffering capacity, such as SNc DA neurons, would be at the bad end of the respiratory reserve distribution of neurons, putting them at risk for insults (Fig. 4A).

But if this type of neuronal design puts neurons at risk, why wouldn't evolution have eliminated it? It appears that most of the neuronal systems that have adopted this phenotype are very tolerant of cell loss. For example, roughly three-quarters of the SNc DA neuron popula- tion must be lost before the motor symptoms are severe enough to prompt a visit to the neurologist (Zigmond et al. 1990). This takes, on average, six decades to occur, which is well past the reproductive period and well past the normal life expectancy until recently. As a consequence, there could not be any evolutionary pressure to change this design.

Is this design merely an accident or unintended consequence of a larger genetic program controlling the SNc DA neuron phenotype? There are some reasons to believe that it is not an accident but an adaptation with unintended consequences. Although not necessary, L-type $\mathrm{Ca}^{2+}$ channel currents do increase the robustness of pacemaking in SNc DA neurons (Guzman et al. 2009); as pacemaking is critical to maintaining normal basal ganglia function, designing a redundant, fail-safe system makes some sense. Dendritic L-type $\mathrm{Ca}^{2+}$ channels also have been shown to boost the frequency
A

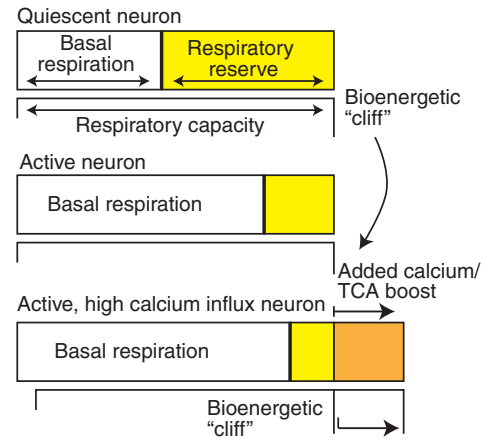

B

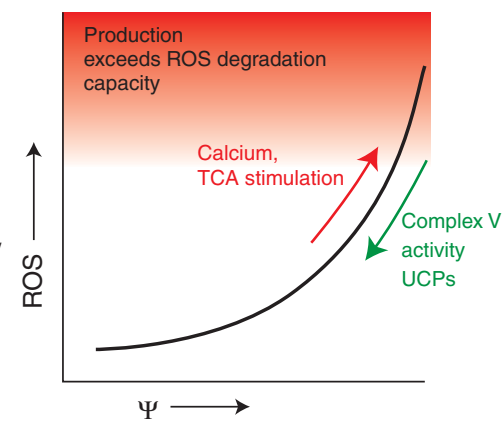

C

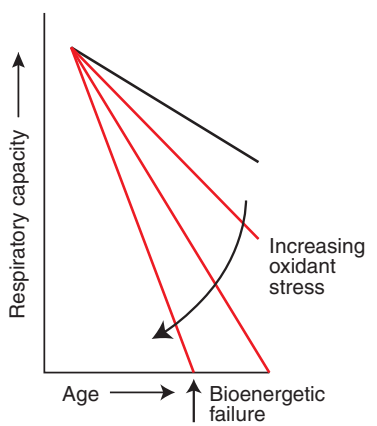

Figure 4. Neurons with the pacemaking phenotype might have a diminished respiratory reserve, putting them at risk of bioenergetics failure. $(A)$ Schematic model of the respiratory capacity of a quiescent neuron, an active neuron, and an active $\mathrm{Ca}^{2+}$-regulated neuron. Respiratory capacity here is defined as the sum of the basal respiration of sustained cellular function and the respiratory reserve, which represents the "back-up" extra fuel for the cell that is normally used under active conditions (e.g., an excitable neuron). Active neurons with a $\mathrm{Ca}^{2+}$ handling phenotype like SNc DA neurons, reach a bioenergetics cliff owing to the enhanced stimulation of the tricarboxylic Krebs cycle (TCA) by $\mathrm{Ca}^{2+}$. This boost increases respiratory capacity of the cell to generate and supply more ATP necessary to support further $\mathrm{Ca}^{2+}$ extrusion. (B) Hypothetical plot of ROS production by the electron transport chain (ETC) as a function of inner mitochondrial membrane potential. Also plotted are the effects of $\mathrm{Ca}^{2+}$ stimulation of the TCA cycle and the effects of complex V and uncoupling proteins (UCPs). (C) Metabolic demand expressed as an increase in respiratory capacity comes at a trade-off of generating reactive oxygen species (ROS) (shown in the graph as the increase in oxidant stress), which will feedback to negatively affect proteostatic function and compromise cellular respiration until it reaches the point of a bioenergetics failure, in which a cell can no longer meet the metabolic demand and will fail to continuously supply the cell with energy fuel to extrude $\mathrm{Ca}^{2+}$. 
D.J. Surmeier et al.

of synaptically driven spiking in SNc DA neurons (Wilson and Callaway 2000; Medvedev et al. 2003); although this enhancement in "burst" spiking is modest, it could elevate DA release just enough to have conferred some survival value by facilitating striatal motor learning. Another possibility is that the expression of $\mathrm{Ca}^{2+}$ channels is an outgrowth of the modest respiratory reserve conferred by the pacemaking phenotype (Fig. 4B). $\mathrm{Ca}^{2+}$ entry into the mitochondrial matrix accelerates the TCA cycle and increases respiratory capacity. Denton and McCormack (1986) showed that the activities of pyruvate dehydrogenase, isocitrate dehydrogenase-3 (IDH3) and 2-oxoglutarate dehydrogenase are enhanced by low micromolar concentrations of $\mathrm{Ca}^{2+}$, so the uptake of cytosolic $\mathrm{Ca}^{2+}$ into the matrix is likely to enhance the generation of reducing equivalents that feed into the electron transport chain. If this increase in capacity exceeds the cost associated with $\mathrm{Ca}^{2+}$ extrusion, then it would increase the respiratory reserve and the resilience to insults and transient stress. This is a strategy used by muscle to deal with the metabolic burden created by contraction. The trick is that supply and demand needs to be matched. Accelerating the TCA and the supply of electrons to the ETC in the absence of increased ATP demand leads to hyperpolarization of the inner mitochondrial membrane (IMM) and increased ROS production (Brand et al. 2004a,b). Matching is straightforward in muscle because the ER orchestrates both the increased supply (increased respiration) and the increased demand (contraction). But this is not the case in neurons (at least it is not obvious). If anything, ER release of $\mathrm{Ca}^{2+}$ is associated with activation of $\mathrm{Ca}^{2+}$-dependent $\mathrm{K}^{+}$channels and decreased spiking (Morikawa et al. 2003). Although plausible and consistent with much of what is known about metabolic regulation in neurons, our understanding of these processes is cursory at best. Much more needs to be done in intact neurons that generate normal patterns of activity to determine whether this hypothesis has merit.

Can oxidant stress (regardless of how it is generated) and mtDNA damage induced by oxidants explain the selective loss of SNc DA neu- rons in PD? Deletion mutations in mtDNA can arise when $\mathrm{H}_{2} \mathrm{O}_{2}$ in the matrix introduces double-strand breaks; accordingly the frequency of these mutations is decreased in hearts of mice expressing mitochondrial catalase (Vermulst et al. 2008). In two studies published simultaneously, Bender et al. (2006) and Kraytsberg et al. (2006) assessed the abundance of mitochondrial DNA deletions, as opposed to point mutations, in SNc neurons from human subjects. Compared to younger subjects, the number of mtDNA deletions was significantly greater in SNc neurons from older subjects. In contrast, undetectable levels of deletions were found in cerebral cortex, cerebellum, or dentate nucleus of aged individuals (Kraytsberg et al. 2006). This indicates that cell-specific differences in the occurrence of deletions can exist, consistent with the cell-specific manifestations of PD. Comparisons among single neurons from the same subject revealed that one neuron might contain no deletions, whereas another would contain multiple copies of a single species-indicating that they originated from a single initial mutant DNA copy that was clonally amplified in that cell (Kraytsberg et al. 2006). The mechanisms responsible for the clonal expansion of a single deletion mutant copy of mtDNA are not known. But if ongoing accumulation of random mutational events had been occurring, one would expect to find a heterogeneous mixture of point mutations in a given cell. Instead, it appears that distinct somatic deletion mutations have developed with age, occurring independently in multiple cells of SN, leading to the appearance of a heterogeneous patchwork of cells each carrying its own pattern of mtDNA deletion.

The point mutations that accumulate in the polymerase- $\gamma$ (POLG) mutant mice can shorten lifespan when they exceed a critical level (Kujoth et al. 2005), but there is no evidence to suggest that either the homozygous or the heterozygous mice develop motor control defects as they age, or that they develop excessive oxidant stress as a consequence of these mutations. In contrast, normal SNc neurons do show enhanced mitochondrial oxidant stress by virtue of their $\mathrm{Ca}^{2+}$ handling, and the formation of 
$\mathrm{H}_{2} \mathrm{O}_{2}$ can induce deletion mutations in mtDNA. These observations suggest that the accumulation of point mutations leading to an augmentation of mitochondrial oxidant stress is not likely to explain the demise of SNc neurons in PD.

An unresolved question is whether the induction of deletion mutations in mtDNA of SNc neurons can lead to an amplification of the ROS generation and trigger the "vicious cycle" hypothesis within this selective population of cells. Deletions of mtDNA can lead to the expression of truncation mutant proteins, or to the complete loss of subunit expression. When one subunit of a mitochondrial complex is genetically deleted, the remaining subunits are still expressed and degraded, which can lead to the generation of an unfolded protein response in the matrix (Zara et al. 2007). For example, Andrew Dillin and colleagues (Durieux et al. 2011) find that deletion of cytochrome oxidase in worm neurons leads to a mitochondrial stress response in the organelle that is transmitted to other tissues and affects lifespan. Byaugmenting mitochondrial, and possibly ER stress responses, deletion mutations in mtDNA can potentially amplify oxidant stress in mitochondria and other cellular compartments, pushing the cell that normally deals with enhanced oxidant stress even closer to the edge. Hence, the cellular consequences of mtDNA damage may depend importantly on the nature of the mutation.

Deletion mutations in mtDNA can potentially augment mitochondrial ROS production by simply blocking the electron transport chain, which then halts the TCA cycle. Complete loss of any protein encoded by a mitochondrial gene is sufficient to abolish electron transport chain function. In that situation, flavin groups, ironsulfur clusters, and heme proteins in the more proximal complexes of the chain remain fully reduced. However, electrons can still escape through the generation of superoxide, augmenting oxidant stress. At the same time, mitochondrial antioxidant capacity is undermined because the loss of electron transport causes the TCA cycle to halt, preventing the generation of NADPH. The scavenging of $\mathrm{H}_{2} \mathrm{O}_{2}$ by glutathi-
Physiological Phenotype in Parkinson's Disease

one peroxidases and peroxiredoxins depends on the presence of reduced glutathione (GSH), which is required by the reductases that sustain their activity. Likewise, the reduction of oxidized mitochondrial protein thiols by glutaredoxin and Trx 2 requires GSH. The oxidized glutathione generated by these reductase systems is re-reduced to GSH using NADPH generated by the TCA cycle. Hence, the loss of a single mitochondrial gene can augment mitochondrial ROS generation and simultaneously undermine the ability of mitochondria to deal with that stress by limiting the supply of NADPH needed for antioxidant functions.

Mitochondrial DNA deletion mutations can also affect cell survival through a bioenergetic mechanism. When the abundance of damaged mtDNA is below a critical level, the normal copies of mtDNA can supply the organelle with adequate levels of the encoded proteins to maintain function and ATP production. However, when the abundance of the mutant form exceeds a critical level (typically 60\%), the phenotypic defect in function becomes evident. Accordingly, Kraytsberg et al. (2006) found that the presence of mtDNA deletions correlated strongly with the absence of cytochrome oxidase immunostaining (Bender et al. 2006). Mitochondrial DNA encodes three critical subunits of cytochrome oxidase, so these findings suggest that the accumulation of mtDNA deletions is responsible for the development of respiratory insufficiency in the affected cells. DA neurons of SNc depend on mitochondrial DNA for survival (Ekstrand et al. 2007), so the accumulation of these mutations can potentially lead to the development of a bioenergetic deficiency that becomes lethal over time. As discussed previously, loss of functionality in the electron transport chain shifts the mitochondria to become ATP consumers, further stressing the bioenergetic status of the cell. In PD, it is conceivable that the progressive clonal expansion of the deletion mutant could occur over many years, resulting in the progressive demise of DA cells.

How do SNc neurons in aged subjects compare with those from individuals with PD? Bender et al. (2006) found that the degree of 
D.J. Surmeier et al.

mtDNA deletions was somewhat higher in neurons from affected individuals compared with aged control subjects. This was associated with a significantly greater proportion of cytochrome oxidase-deficient cells, compatible with the idea that bioenergetic crisis could be responsible for the progressive cellular loss. Consistent with the study of Kraytsberg et al. (2006), this group detected clonal expansion of the unique species of mtDNA deletions in individual SNc neurons, indicating that these are indeed somatic mutations. In contrast, high levels of deleted mtDNA were not detected in hippocampus.

\section{What about Non-DA Neurons in PD?}

Many lines of study ranging from histological analysis of PD brains to clinical examination of PD patients have made it clear that pathogenesis is not limited to SNc DA neurons. Based on LB/ LN pathology, in the early and middle stages of the disease, many small groups of neurons in the brain stem, diencephalon, and telencephalon are affected. Foremost among these are neurons in the dorsal motor nucleus of the vagus (DMV), in the locus coeruleus, in the raphe nuclei, in the gigantocellularis nucleus, in the tuberomamillary nucleus of the hypothalamus, in the olfactory bulb, and in the basal forebrain (German et al. 1992b; Del Tredici and Braak 2004).

Most of these neurons have not been studied in detail, but enough is known to draw a couple of conclusions. First, all of these nuclei are dominated by neurons that are spontaneously active (Williams et al. 1984; Chan and Chan 1989; McCann and Rogers 1990; Serafin et al. 1990; Travagli et al. 1991; Aston-Jones 2005). Second, many of these neurons have broad action potentials. Much less is known about whether these neurons share the other phenotypic features of SNc DA neurons that are likely to determine vulnerability, such as prominent $\mathrm{Ca}^{2+}$ currents. What is known is consistent with this hypothesis. For example, raphe neurons show pronounced $\mathrm{Ca}^{2+}$-dependent pacemaking potentials (Burlhis and Aghajanian 1987). Both locus coeruleus and tuberomamillary neurons are autonomous pacemakers that en- gage L-type $\mathrm{Ca}^{2+}$ channels (Williams et al. 1984; Stevens and Haas 1996; Taddese and Bean 2002). Our unpublished work also has found that locus coeruleus neurons also have low intrinsic $\mathrm{Ca}^{2+}$-buffering capacity and basal mitochondrial oxidant stress that is sensitive to L-type channel antagonism. DA neurons in the olfactory bulb also are autonomous pacemakers and rely on $\mathrm{Ca}^{2+}$ channels (although not L-type channels) (Pignatelli et al. 2005; Puopolo et al. 2005). Although olfactory deficits have been associated with PD (Postuma et al. 2006), there is no obvious loss of olfactory bulb DA neurons (Huisman et al. 2008). Although this would seem to run counter to the phenotype hypothesis, this could simply be a consequence of the capacity of this region for adult neurogenesis (Pignatelli et al. 2009). Thus, a reasonable hypothesis is that all of the neurons displaying a strong risk in PD share a common physiological phenotype.

\section{RECONCILIATION WITH CURRENT MODELS OF PD PATHOGENESIS}

The proposition that a neuronal phenotype leads to excessive mitochondrial oxidant stress, mitochondrial DNA deletion, and bioenergetic deficiency is consistent with a large body of evidence implicating these organelles in PD pathogenesis (Schapira 2011; Trancikova et al. 2011). The following are important questions in that model that still need to be addressed: Does the oxidant stress extend from the mitochondria to other parts of the cell? Is oxidant stress responsible for the demise of the dopaminergic SNc cells in humans? What are the targets of the oxidant stress that lead to that demise, and what mechanisms link the neuronal phenotype to the long latent period before the onset of disease symptoms?

Another prominent theory in the field is that $\mathrm{PD}$ is essentially a protein misfolding or proteostatic disorder (Bosco et al. 2011). The presence of Lewy bodies and Lewy neurites in substantia nigra is a common finding in patients with $\mathrm{PD}$; the major filamentous protein component of the LBs and LNs is $\alpha$-synuclein (Spillantini et al. 1998). Mutations in the $\alpha$-synuclein 
gene lead to early-onset autosomal-dominant forms of inherited PD associated with the accumulation of $\alpha$-synuclein aggregates in humans, providing a strong link to the disease (Polymeropoulos et al. 1997; Kruger et al. 1998; Dawson and Dawson 2003a,b; Berg et al. 2005). Accumulation of misfolded proteins can occur when an imbalance develops between the factors tending to promote protein unfolding (oxidant stress, $\mathrm{pH}$ stress, thermal shock, prion-mediated disruption) and the systems responsible for removal (ubiquitinylation, proteasomes) or refolding (molecular chaperones). It is therefore reasonable to expect that mutations promoting misfolding of an abundantly expressed protein can lead to a disruption of this balance and the accumulation of aggregates, with functional consequences for cell survival. Indeed the expression of mutant versions of $\alpha$-synuclein in flies leads to the development of motor control defects and inclusion bodies that resemble PD in humans (Feany and Bender 2000). However, in patients with PD who lack such mutations, it is not clear whether the cell death is caused by the accumulation of these aggregates.

Deficits in proteasome clearance of misfolded proteins and autophagy have unequivocally been linked to neurodegeneration in animal models of PD (Shastry 2003). In some cases the cellular degeneration may result from a nonspecific accumulation of disordered proteins such as $\alpha$-synuclein, but in other cases it can develop because a specific functional protein is not cleared normally. In that regard, genetic defects in Parkin, an E3 ubiquitin ligase, have been linked to human PD (Shimura et al. 2000). A protein target of Parkin is PARIS, which functions as a transcriptional repressor of peroxisome proliferator-activated receptor $\gamma(\operatorname{PPAR} \gamma)$ cofactor- $1 \alpha$ (PGC- $1 \alpha)$ (Shin et al. 2011). PGC- $1 \alpha$ is a major regulator of mitochondrial biogenesis (Lin et al. 2002), so suppression of its activity by PARIS, which accumulates in the absence of Parkin, could drive cells toward bioenergetic deficiency by limiting the number of mitochondria. Indeed, deletion of Parkin from SN led to progressive loss of dopaminergic neurons in a PARIS-dependent manner (Shin et al. 2011).
Physiological Phenotype in Parkinson's Disease

In the case of $\alpha$-synuclein, it is not known whether the aggregation of wild-type $\alpha$-synuclein in the aging human is a proximal initiator of PD, whether it contributes to the cell death as a distal effector, or whether it represents a marker of a cell already committed to a terminal pathway. Some evidence suggests that oxidation of methionine residues in $\alpha$-synuclein (which lacks cysteine residues) may promote its accumulation as a stable oligomer while preventing the fibrillation of unmodified $\alpha$-synuclein (for review see Glaser et al. 2005). In view of our data linking the cellular $\mathrm{Ca}^{2+}$ phenotype to the generation of oxidant stress, it is conceivable that the oxidative modification of $\alpha$-synuclein could lead to its subsequent oligomerization in dopaminergic SNc cells. A number of studies have provided evidence that elevated $\mathrm{Ca}^{2+}$ concentration promotes aggregation of $\alpha$-synuclein (Gomez-Tortosa et al. 2001; Nielsen et al. 2001; Lowe et al. 2004; Tamamizu-Kato et al. 2006; Esteves et al. 2010; Fortin et al. 2010; Nath et al. 2011). It is also possible that $\alpha$-synuclein toxicity compromises $\mathrm{Ca}^{2+}$ homeostasis, particularly in neurons like SNc DA neurons where $\mathrm{Ca}^{2+}$ poses a challenge normally (Mattson 2007; Hettiarachchi et al. 2009; Belal et al. 2011; Vekrellis et al. 2011). As the oligomers of $\alpha$ synuclein may be cytotoxic, this mechanism furthers the notion that the phenotype of these neurons, their $\mathrm{Ca}^{2+}$-dependent ROS generation, and their tendency to express a protein that is vulnerable to forming toxic aggregates when oxidized, may explain the cell-specific manifestations of the disease. Furthermore, the clearance of misfolded proteins requires energy in the form of ATP, so the bioenergetic consequences of mitochondrial dysfunction (discussed earlier) could further compromise the clearance of misfolded proteins, leading to their accumulation in protein dumps that grow to become LBs and LNs (Esteves et al. 2011).

\section{ARE L-TYPE $\mathrm{Ca}^{2+}$ CHANNELS A VIABLE THERAPEUTIC TARGET?}

Although there are several factors governing the loss of SNc DA neurons, most of them cannot be manipulated. The exception is the engagement of 
D.J. Surmeier et al.

L-type $\mathrm{Ca}^{2+}$ channels. These channels are antagonized by orally deliverable dihydropyridines with good brain bioavailability that have a long record of safe use in humans (Yamada et al. 1990; German et al. 1992a; Chan et al. 2007; Guzman et al. 2010; Ilijic et al. 2011). SNc DA neurons that express the $\mathrm{Ca}^{2+}$-binding protein calbindin have a diminished sensitivity to toxins and to PD (Yamada et al. 1990; German et al. 1992a).

Is there evidence that DHP use might work in humans to prevent or slow $\mathrm{PD}$ ? $\mathrm{Ca}^{2+}$ channel antagonists (CCAs), including the DHPs used in animal studies, are commonly used in clinical practice to treat hypertension, creating a potential database to be mined. A case-control study of hypertensive patients found a significant reduction in the observed risk of PD with CCA use, but not with medications that reduce blood pressure in other ways (Becker et al. 2008). More recently, a large Danish data set has been examined (Ritz et al. 2010). The investigators agreed with the main conclusions of the Becker et al. study but extended their findings by showing that only DHPs that cross the blood-brain barrier $(\mathrm{BBB})$ are associated with reduced PD risk ( $\sim 30 \%)$. Given the short period of treatment in many cases $(\sim 2 \mathrm{yr})$, variable dosing, and low relative affinity of DHPs for $\mathrm{Ca}_{\mathrm{v}} 1.3 \mathrm{Ca}^{2+}$ channels (compared to $\mathrm{Ca}_{\mathrm{v}} 1.2$ channels (Mannhold et al. 1995; Kupsch et al. 1996; Eisenberg et al. 2004), this is a surprisingly strong association and lends further credence to the proposition that a BBB-permeable and potent $\mathrm{Ca}_{\mathrm{v}} 1.3$ antagonist could be a very effective neuroprotective agent. It should be noted that a small, recent study (Simon et al. 2010) failed to find a significant relationship between use of $\mathrm{Ca}^{2+}$ channel antagonists and PD risk; however, this study did not take into account the type of $\mathrm{Ca}^{2+}$ channel antagonist used or the pharmacokinetic properties of the compounds. This undermines any conclusion to be drawn from the study. After all, Ritz et al. (2010) showed that even amlodipine-a DHP with reasonable affinity for $\mathrm{Ca}_{\mathrm{v}} \mathrm{1}$ channels-does not reduce the observed risk of developing PD, but amlodipine does not cross the blood-brain barrier.

Although strongly suggestive, epidemiological studies are not a substitute for a prospective controlled clinical trial. In the absence of a selective $\mathrm{Ca}_{\mathrm{v}} 1.3 \mathrm{Ca}^{2+}$ channel antagonist, the DHP isradipine is the most attractive drug for such a trial. Isradipine has a relatively higher affinity for $\mathrm{Ca}_{\mathrm{v}} 1.3 \mathrm{Ca}^{2+}$ channels than the other known DHP and has good brain bioavailability (Koschak et al. 2001; Scholze et al. 2001). At the doses used to treat hypertension, isradipine has relatively minor side effects (Fitton and Benfield 1990). The question is whether it will prove neuroprotective at doses tolerated by the general population. Pharmacokinetic studies by our group have found that plasma concentrations of isradipine achieved in mice that are protected against systemic 1-methyl-4-phenyl-1,2,3,6-tetrahydropyridine (MPTP) administration are very close to those achieved in humans with a very well tolerated daily dose of isradipine ( 2-4 $\mathrm{ng} / \mathrm{mL}$ in mice; $1-2 \mathrm{ng} / \mathrm{mL}$ in humans at $10 \mathrm{mg} / \mathrm{d}$, Dynacirc CR), suggesting that neuroprotection is achievable. A more recent study using an intrastriatal 6-hydroxydopamine model has shown that systemic administration of isradipine produces a dose-dependent protection of both SNc DA axon terminals and cell bodies at plasma concentrations in a similar range (IC50 $\sim 4-8 \mathrm{ng} / \mathrm{mL}$ ) (Ilijic et al. 2011). The plasma concentrations required for significant protection against this acute challenge were greater than those needed in the chronic MPTP model, but were are still near the range achievable in humans. It is important to note that these studies suggest that protection is afforded by partial antagonism of $\mathrm{Ca}_{\mathrm{v}} 1.3$ channels, minimizing any complications that might attend near complete disruption of these channels. Using a modulated receptor model derived from an early paper by Bean (1984), Ilijic et al. estimated that $\sim 40 \%-60 \%$ of the $\mathrm{Ca}_{\mathrm{v}} 1.3$ channels were antagonized at the half-maximal dose for protection from intrastriatal 6-OHDA injection. Given the slow progression of $\mathrm{PD}$, it is highly likely that a more modest antagonism would suffice in humans.

The ideal candidate for DHP therapy would be in the very early stages of SNc loss, before the onset of symptoms. Unfortunately, there are no biomarkers that would allow the identification of presymptomatic PD patients. As a 
consequence, the most likely subjects for a clinical trial are those that have been recently diagnosed with PD. In these early-stage patients, SNc DA cell loss is substantial $(>60 \%)$ and the remaining neurons might be compromised in ways not seen in healthy tissue. Nevertheless, disease progression could be tracked in a longitudinal study to determine whether treated patients show a slower rate of motor deficit progression. There is growing evidence that inflammation could have an important impact on disease progression at this stage (Hirsch and Hunot 2009). Antagonism of L-type channels might be helpful but not enough to significantly slow progression if this is the case.

It is also worth considering how DHPs compare with other drugs that are being tested in clinical neuroprotection trials for PD. Although early trials with creatine, coenzyme Q10, and the mitochondrial antioxidant compound MitoQ have been disappointing (Shults et al. 1997), this is not sufficient evidence to reject the idea that oxidative stress contributes to PD. Coenzyme Q10 is an electron acceptor for complexes I and II that appears compromised in PD patients (Shults et al. 1997) and is neuroprotective in animal models of PD (Beal et al. 1998). MitoQ is a mitochondria-targeted version of coenzyme Q10 that functions as a scavenger of mitochondrial oxidants (Smith and Murphy 2011). Creatine is a substrate for ATP production that can both improve mitochondrial efficiency and reduce oxidative stress by buffering fluctuations in cellular energy production (Matthews et al. 1999). One possibility is that antioxidant treatment initiated after the point of clinical diagnosis is ineffective because the cells have already accumulated a critical level of damage. By analogy, myocardial damage in ischemia-reperfusion is mediated by excessive oxidant stress, yet antioxidants given in the days after myocardial infarction are ineffective at rescuing cell function because the oxidant damage is already done. It is also important to consider that the effect of antioxidants will depend on where the oxidant stress is generated and where the critical targets of these oxidants reside. Clearly, an antioxidant distributed, for example, in membranes could be minimally ef-
Physiological Phenotype in Parkinson's Disease

fective in scavenging oxidants in the mitochondrial matrix. If antioxidant therapy by itself is ineffective, then approaches aimed at improving mitochondrial function rather than attacking the source of stress on mitochondria could be more effective. For example, deprenyl could prove to have neuroprotective effects by virtue not of its ability to inhibit the degradation of DA, but by its ability to induce the expression of antioxidant defenses (Magyar and Szende 2004). Because their sites of action differ within the chain of events leading to oxidative stress and mitochondrial dysfunction, a combination therapy could prove more effective than any one alone.

\section{ACKNOWLEDGMENTS}

This work is supported by grants from the Hartman Foundation, USAMRMC, and NIH (NS047085, RR025355, and HL35440).

\section{REFERENCES}

Aguilaniu H, Durieux J, Dillin A. 2005. Metabolism, ubiquinone synthesis, and longevity. Genes Dev 19: 23992406.

Aston-Jones G. 2005. Brain structures and receptors involved in alertness. Sleep Med 6: S3-S7.

Atherton JF, Bevan MD. 2005. Ionic mechanisms underlying autonomous action potential generation in the somata and dendrites of GABAergic substantia nigra pars reticulata neurons in vitro. J Neurosci 25: 8272-8281.

Augustine GJ, Santamaria F, Tanaka K. 2003. Local calcium signaling in neurons. Neuron 40: 331-346.

Bardo S, Cavazzini MG, Emptage N. 2006. The role of the endoplasmic reticulum $\mathrm{Ca}^{2+}$ store in the plasticity of central neurons. Trends Pharmacol Sci 27: 78-84.

Baris OR, Klose A, Kloepper JE, Weiland D, Neuhaus JF, Schauen M, Wille A, Muller A, Merkwirth C, Langer T, et al. 2011. The mitochondrial electron transport chain is dispensable for proliferation and differentiation of epidermal progenitor cells. Stem Cells 29: 1459-1468.

Baysal BE, Ferrell RE, Willett-Brozick JE, Lawrence EC, Myssiorek D, Bosch A, van der Mey A, Taschner PE, Rubinstein WS, Myers EN, et al. 2000. Mutations in SDHD, a mitochondrial complex II gene, in hereditary paraganglioma. Science 287: 848-851.

Beal MF. 1995. Aging, energy, and oxidative stress in neurodegenerative diseases. Ann Neurol 38: 357-366.

Beal MF, Matthews RT, Tieleman A, Shults CW. 1998. Coenzyme Q10 attenuates the 1-methyl-4-phenyl-1,2,3,tetrahydropyridine (MPTP) induced loss of striatal dopamine and dopaminergic axons in aged mice. Brain Res 783: 109-114. 


\section{D.J. Surmeier et al.}

Bean BP. 1984. Nitrendipine block of cardiac calcium channels: High-affinity binding to the inactivated state. Proc Natl Acad Sci 81: 6388-6392.

Bean BP. 2007. The action potential in mammalian central neurons. Nat Rev Neurosci 8: 451-465.

Becker C, Jick SS, Meier CR. 2008. Use of antihypertensives and the risk of Parkinson disease. Neurology 70: 1438 1444.

Beckman KB, Ames BN. 1998. The free radical theory of aging matures. Physiol Rev 78: 547-581.

Belal C, Ameli NJ, El Kommos A, Bezalel S, Al'khafaji AM, Mughal MR, Mattson MP, Kyriazis GA, Tyrberg B, Chan SL. 2011. The homocysteine-inducible endoplasmic reticulum (ER) stress protein Herp counteracts mutant $\alpha$ synuclein-induced ER stress via the homeostatic regulation of ER-resident calcium release channel proteins. Hum Mol Genet 21: 963-977.

Belzunegui S, San Sebastian W, Garrido-Gil P, Izal-Azcarate A, Vazquez-Claverie M, Lopez B, Marcilla I, Lanciego JL, Luquin MR. 2007. The number of dopaminergic cells is increased in the olfactory bulb of monkeys chronically exposed to MPTP. Synapse 61: 1006-1012.

Bender A, Krishnan KJ, Morris CM, Taylor GA, Reeve AK, Perry RH, Jaros E, Hersheson JS, Betts J, Klopstock T, et al. 2006. High levels of mitochondrial DNA deletions in substantia nigra neurons in aging and Parkinson disease. Nat Genet 38: 515-517.

Berg D, Niwar M, Maass S, Zimprich A, Moller JC, Wuellner U, Schmitz-Hubsch T, Klein C, Tan EK, Schols L, et al. 2005. $\alpha$-Synuclein and Parkinson's disease: Implications from the screening of more than 1,900 patients. Mov Disord 20: 1191-1194.

Berridge MJ. 2002. The endoplasmic reticulum: A multifunctional signaling organelle. Cell Calcium 32: 235-249.

Boldogh IR, Pon LA. 2007. Mitochondria on the move Trends Cell Biol 17: 502-510.

Bonci A, Grillner P, Mercuri NB, Bernardi G. 1998. L-Type calcium channels mediate a slow excitatory synaptic transmission in rat midbrain dopaminergic neurons. $J$ Neurosci 18: 6693-6703.

Bosco DA, LaVoie MJ, Petsko GA, Ringe D. 2011. Proteostasis and movement disorders: Parkinson's disease and amyotrophic lateral sclerosis. Cold Spring Harb Perspect Biol 3: a007500.

Braak H, Del Tredici K, Rub U, de Vos RA, Jansen Steur EN, Braak E. 2003. Staging of brain pathology related to sporadic Parkinson's disease. Neurobiol Aging 24: 197211.

Braak H, Ghebremedhin E, Rub U, Bratzke H, Del Tredici K. 2004. Stages in the development of Parkinson's diseaserelated pathology. Cell Tissue Res 318: 121-134.

Brand MD, Affourtit C, Esteves TC, Green K, Lambert AJ, Miwa S, Pakay JL, Parker N. 2004a. Mitochondrial superoxide: Production, biological effects, and activation of uncoupling proteins. Free Radic Biol Med 37: 755-767.

Brand MD, Buckingham JA, Esteves TC, Green K, Lambert AJ, Miwa S, Murphy MP, Pakay JL, Talbot DA, Echtay KS. 2004b. Mitochondrial superoxide and aging: Uncoupling-protein activity and superoxide production. Biochem Soc Symp 71: 203-213.
Burlhis TM, Aghajanian GK. 1987. Pacemaker potentials of serotonergic dorsal raphe neurons: Contribution of a low-threshold $\mathrm{Ca}^{2+}$ conductance. Synapse 1: 582-588.

Cardenas C, Miller RA, Smith I, Bui T, Molgo J, Muller M, Vais H, Cheung KH, Yang J, Parker I, et al. 2010. Essential regulation of cell bioenergetics by constitutive InsP3 receptor $\mathrm{Ca}^{2+}$ transfer to mitochondria. Cell 142: 270-283.

Chan JY, Chan SH. 1989. Passive electrical properties of spontaneously active neurons in the nucleus reticularis gigantocellularis of the cat. Neurosci Lett 97: 169-174.

Chan CS, Shigemoto R, Mercer JN, Surmeier DJ. 2004. HCN2 and HCN1 channels govern the regularity of autonomous pacemaking and synaptic resetting in globus pallidus neurons. J Neurosci 24: 9921-9932.

Chan CS, Guzman JN, Ilijic E, Mercer JN, Rick C, Tkatch T, Meredith GE, Surmeier DJ. 2007. "Rejuvenation" protects neurons in mouse models of Parkinson's disease. Nature 447: 1081-1086.

Chan CS, Glajch KE, Gertler TS, Guzman JN, Mercer JN, Lewis AS, Goldberg AB, Tkatch T, Shigemoto R, Fleming SM, et al. 2011. HCN channelopathy in external globus pallidus neurons in models of Parkinson's disease. Nat Neurosci 14: 85-92.

Chen KC, Chang LS. 2009. Arachidonic acid-induced apoptosis of human neuroblastoma SK-N-SH cells is mediated through mitochondrial alteration elicited by ROS and $\mathrm{Ca}^{2+}$-evoked activation of $\mathrm{p} 38 \alpha$ MAPK and JNK1. Toxicology 262: 199-206.

Choi YM, Kim SH, Chung S, Uhm DY, Park MK. 2006. Regional interaction of endoplasmic reticulum $\mathrm{Ca}^{2+}$ signals between soma and dendrites through rapid luminal $\mathrm{Ca}^{2+}$ diffusion. J Neurosci 26: 12127-12136.

Choi SW, Gerencser AA, Lee DW, Rajagopalan S, Nicholls DG, Andersen JK, Brand MD. 2011. Intrinsic bioenergetic properties and stress sensitivity of dopaminergic synaptosomes. J Neurosci 31: 4524-4534.

Clapham DE. 2007. Calcium signaling. Cell 131: 10471058.

Commoner B, Townsend J, Pake GE. 1954. Free radicals in biological materials. Nature 174: 689-691.

Cookson MR. 2010. Unravelling the role of defective genes. Prog Brain Res 183: 43-57.

Cookson MR, Bandmann O. 2010. Parkinson's disease: Insights from pathways. Hum Mol Genet 19: R21-R27.

Csordas G, Renken C, Varnai P, Walter L, Weaver D, Buttle KF, Balla T, Mannella CA, Hajnoczky G. 2006. Structural and functional features and significance of the physical linkage between ER and mitochondria. J Cell Biol 174: 915-921.

Cui G, Okamoto T, Morikawa H. 2004. Spontaneous opening of T-type $\mathrm{Ca}^{2+}$ channels contributes to the irregular firing of dopamine neurons in neonatal rats. J Neurosci 24: 11079-11087.

Damier P, Hirsch EC, Agid Y, Graybiel AM. 1999. The substantia nigra of the human brain. II. Patterns of loss of dopamine-containing neurons in Parkinson's disease. Brain 122: $1437-1448$.

Dawson TM, Dawson VL. 2003a. Molecular pathways of neurodegeneration in Parkinson's disease. Science 302: $819-822$. 
Dawson TM, Dawson VL. 2003b. Rare genetic mutations shed light on the pathogenesis of Parkinson disease. $J$ Clin Invest 111: 145-151.

de Brito OM, Scorrano L. 2008. Mitofusin 2 tethers endoplasmic reticulum to mitochondria. Nature 456: $605-$ 610.

de Lau LM, Giesbergen PC, de Rijk MC, Hofman A, Koudstaal PJ, Breteler MM. 2004. Incidence of parkinsonism and Parkinson disease in a general population: The Rotterdam Study. Neurology 63: 1240-1244.

Del Tredici K, Braak H. 2004. Idiopathic Parkinson's disease: Staging an $\alpha$-synucleinopathy with a predictable pathoanatomy. In Molecular mechanisms of Parkinson's disease (ed. Kahle PJ, Haas C), pp. 1-32. Landes Bioscience, Georgetown, TX.

Denton RM, McCormack JG. 1986. The calcium sensitive dehydrogenases of vertebrate mitochondria. Cell Calcium 7: $377-386$.

de Rijk MC, Tzourio C, Breteler MM, Dartigues JF, Amaducci L, Lopez-Pousa S, Manubens-Bertran JM, Alperovitch A, Rocca WA. 1997. Prevalence of parkinsonism and Parkinson's disease in Europe: The EUROPARKINSON Collaborative Study. European community concerted action on the epidemiology of Parkinson's disease. J Neurol Neurosurg Psychiatry 62: 10-15.

De Stefani D, Raffaello A, Teardo E, Szabo I, Rizzuto R. 2011. A forty-kilodalton protein of the inner membrane is the mitochondrial calcium uniporter. Nature 476: 336-340.

Ding JB, Guzman JN, Peterson JD, Goldberg JA, Surmeier DJ. 2010. Thalamic gating of corticostriatal signaling by cholinergic interneurons. Neuron 67: 294-307.

Dorsey ER, Constantinescu R, Thompson JP, Biglan KM, Holloway RG, Kieburtz K, Marshall FJ, Ravina BM, Schifitto G, Siderowf A, et al. 2007. Projected number of people with Parkinson disease in the most populous nations, 2005 through 2030. Neurology 68: 384-386.

Durieux J, Wolff S, Dillin A. 2011. The cell-non-autonomous nature of electron transport chain-mediated longevity. Cell 144: 79-91.

Eisenberg MJ, Brox A, Bestawros AN. 2004. Calcium channel blockers: An update. Am J Med 116: 35-43.

Ekstrand MI, Terzioglu M, Galter D, Zhu S, Hofstetter C, Lindqvist E, Thams S, Bergstrand A, Hansson FS, Trifunovic A, et al. 2007. Progressive parkinsonism in mice with respiratory-chain-deficient dopamine neurons. Proc Natl Acad Sci 104: 1325-1330.

Esteves AR, Arduino DM, Swerdlow RH, Oliveira CR, Cardoso SM. 2010. Microtubule depolymerization potentiates $\alpha$-synuclein oligomerization. Front Aging Neurosci 1: 5 .

Esteves AR, Arduino DM, Silva DF, Oliveira CR, Cardoso SM. 2011. Mitochondrial dysfunction: The road to $\alpha$ synuclein oligomerization in PD. Parkinson's Dis 2011: 693761.

Fahn S. 2005. Does levodopa slow or hasten the rate of progression of Parkinson's disease? J Neurol 252: IV37IV42.

Feany MB, Bender WW. 2000. A Drosophila model of Parkinson's disease. Nature 404: 394-398.
Physiological Phenotype in Parkinson's Disease

Fitton A, Benfield P. 1990. Isradipine. A review of its pharmacodynamic and pharmacokinetic properties, and therapeutic use in cardiovascular disease. Drugs 40: 31-74.

Foehring RC, Zhang XF, Lee JC, Callaway JC. 2009. Endogenous calcium buffering capacity of substantia nigral dopamine neurons. J Neurophysiol 102: 2326-2333.

Fortin DL, Nemani VM, Nakamura K, Edwards RH. 2010. The behavior of $\alpha$-synuclein in neurons. Mov Disord 25: S21-S26.

Gerfen CR, Surmeier DJ. 2011. Modulation of striatal projection systems by dopamine. Annu Rev Neurosci 34: 441-466.

German DC, Manaye KF, Sonsalla PK, Brooks BA. 1992a. Midbrain dopaminergic cell loss in Parkinson's disease and MPTP-induced parkinsonism: Sparing of calbindinD28k-containing cells. Ann NY Acad Sci 648: 42-62.

German DC, Manaye KF, White CL III, Woodward DJ, McIntire DD, Smith WK, Kalaria RN, Mann DM. 1992b. Disease-specific patterns of locus coeruleus cell loss. Ann Neurol 32: 667-676.

Glaser CB, Yamin G, Uversky VN, Fink AL. 2005. Methionine oxidation, $\alpha$-synuclein and Parkinson's disease. Biochim Biophys Acta 1703: 157-169.

Gomez-Tortosa E, Sanders JL, Newell K, Hyman BT. 2001. Cortical neurons expressing calcium binding proteins are spared in dementia with Lewy bodies. Acta Neuropathol 101: $36-42$.

Greenamyre JT, Hastings TG. 2004. Biomedicine. Parkinson's-Divergent causes, convergent mechanisms. Science 304: 1120-1122.

Gross A, Sims RE, Swinny JD, Sieghart W, Bolam JP, Stanford IM. 2011. Differential localization of $\mathrm{GABA}_{\mathrm{A}}$ receptor subunits in relation to rat striatopallidal and pallidopallidal synapses. Eur J Neurosci 33: 868-878.

Gubitz AK, Gwinn K. 2009. Mining the genome for susceptibility to complex neurological disorders. Curr Mol Med 9: $801-813$.

Guzman JN, Sanchez-Padilla J, Chan CS, Surmeier DJ. 2009. Robust pacemaking in substantia nigra dopaminergic neurons. J Neurosci 29: 11011-11019.

Guzman JN, Sanchez-Padilla J, Wokosin D, Kondapalli J, Ilijic E, Schumacker PT, Surmeier DJ. 2010. Oxidant stress evoked by pacemaking in dopaminergic neurons is attenuated by DJ-1. Nature 468: 696-700.

Guzy RD, Sharma B, Bell E, Chandel NS, Schumacker PT. 2008. Loss of the SdhB, but not the SdhA, subunit of complex II triggers reactive oxygen species-dependent hypoxia-inducible factor activation and tumorigenesis. Mol Cell Biol 28: 718-731.

Hanson GT, Aggeler R, Oglesbee D, Cannon M, Capaldi RA, Tsien RY, Remington SJ. 2004. Investigating mitochondrial redox potential with redox-sensitive green fluorescent protein indicators. J Biol Chem 279: 13044-13053.

Hansson A, Hance N, Dufour E, Rantanen A, Hultenby K, Clayton DA, Wibom R, Larsson NG. 2004. A switch in metabolism precedes increased mitochondrial biogenesis in respiratory chain-deficient mouse hearts. Proc Natl Acad Sci 101: 3136-3141.

Harman D. 1956. Aging: A theory based on free radical and radiation chemistry. J Gerontol 11: 298-300. 
D.J. Surmeier et al.

Hayashi T, Rizzuto R, Hajnoczky G, Su TP. 2009. MAM: More than just a housekeeper. Trends Cell Biol 19: 81-88.

Hettiarachchi NT, Parker A, Dallas ML, Pennington K, Hung CC, Pearson HA, Boyle JP, Robinson P, Peers C. 2009. $\alpha$ Synuclein modulation of $\mathrm{Ca}^{2+}$ signaling in human neuroblastoma (SH-SY5Y) cells. J Neurochem 111: $1192-$ 1201.

Hirsch EC, Hunot S. 2009. Neuroinflammation in Parkinson's disease: A target for neuroprotection? Lancet Neurol 8: $382-397$.

Holmgren A, Sengupta R. 2010. The use of thiols by ribonucleotide reductase. Free Radic Biol Med 49: $1617-$ 1628.

Hornykiewicz O. 1966. Dopamine (3-hydroxytyramine) and brain function. Pharmacol Rev 18: 925-964.

Huisman E, Uylings HB, Hoogland PV. 2008. Gender-related changes in increase of dopaminergic neurons in the olfactory bulb of Parkinson's disease patients. Mov Disord 23: $1407-1413$.

Ilijic E, Guzman JN, Surmeier DJ. 2011. The L-type channel antagonist isradipine is neuroprotective in a mouse model of Parkinson's disease. Neurobiol Dis 43: 364-371.

Ito H, Goto S, Sakamoto S, Hirano A. 1992. CalbindinD28k in the basal ganglia of patients with parkinsonism. Ann Neurol 32: 543-550.

Jang YC, Remmen VH. 2009. The mitochondrial theory of aging: Insight from transgenic and knockout mouse models. Exp Gerontol 44: 256-260.

Jang YC, Perez VI, Song W, Lustgarten MS, Salmon AB, Mele J, Qi W, Liu Y, Liang H, Chaudhuri A, et al. 2009. Overexpression of Mn superoxide dismutase does not increase life span in mice. J Gerontol A Biol Sci Med Sci 64: 11141125.

Jensen PK. 1966a. Antimycin-insensitive oxidation of succinate and reduced nicotinamide-adenine dinucleotide in electron-transport particles. I. $\mathrm{pH}$ dependency and hydrogen peroxide formation. Biochim Biophys Acta 122: $157-166$.

Jensen PK. 1966b. Antimycin-insensitive oxidation of succinate and reduced nicotinamide-adenine dinucleotide in electron-transport particles. II. Steroid effects. Biochim Biophys Acta 122: 167-174.

Jouaville LS, Pinton P, Bastianutto C, Rutter GA, Rizzuto R. 1999. Regulation of mitochondrial ATP synthesis by calcium: Evidence for a long-term metabolic priming. Proc Natl Acad Sci 96: 13807-13812.

Kirichok Y, Krapivinsky G, Clapham DE. 2004. The mitochondrial calcium uniporter is a highly selective ion channel. Nature 427: 360-364.

Kish SJ, Shannak K, Hornykiewicz O. 1988. Uneven pattern of dopamine loss in the striatum of patients with idiopathic Parkinson's disease. Pathophysiologic and clinical implications. N Engl J Med 318: 876-880.

Korshunov SS, Skulachev VP, Starkov AA. 1997. High protonic potential actuates a mechanism of production of reactive oxygen species in mitochondria. FEBS Lett 416: $15-18$.

Koschak A, Reimer D, Huber I, Grabner M, Glossmann H, Engel J, Striessnig J. 2001. $\alpha$ 1D (Cav1.3) subunits can form l-type $\mathrm{Ca}^{2+}$ channels activating at negative voltages. J Biol Chem 276: 22100-22106.
Kraytsberg Y, Kudryavtseva E, McKee AC, Geula C, Kowall NW, Khrapko K. 2006. Mitochondrial DNA deletions are abundant and cause functional impairment in aged human substantia nigra neurons. Nat Genet 38: 518-520.

Kruger R, Kuhn W, Muller T, Woitalla D, Graeber M, Kosel S, Przuntek H, Epplen JT, Schols L, Riess O. 1998. Ala30Pro mutation in the gene encoding $\alpha$-synuclein in Parkinson's disease. Nat Genet 18: 106-108.

Kujoth GC, Hiona A, Pugh TD, Someya S, Panzer K, Wohlgemuth SE, Hofer T, Seo AY, Sullivan R, Jobling WA, et al. 2005. Mitochondrial DNA mutations, oxidative stress, and apoptosis in mammalian aging. Science 309: 481484.

Kupsch A, Sautter J, Schwarz J, Riederer P, Gerlach M, Oertel WH. 1996. 1-Methyl-4-phenyl-1,2,3,6-tetrahydropyridine-induced neurotoxicity in non-human primates is antagonized by pretreatment with nimodipine at the nigral, but not at the striatal level. Brain Res 741: 185196.

Lee CR, Tepper JM. 2007. Morphological and physiological properties of parvalbumin- and calretinin-containing $\gamma$-aminobutyric acidergic neurons in the substantia nigra. J Comp Neurol 500: 958-972.

Lee I, Bender E, Arnold S, Kadenbach B. 2001. New control of mitochondrial membrane potential and ROS formation-A hypothesis. Biol Chem 382: 1629-1636.

Lin J, Wu H, Tarr PT, Zhang CY, Wu Z, Boss O, Michael LF, Puigserver P, Isotani E, Olson EN, et al. 2002. Transcriptional co-activator PGC- $1 \alpha$ drives the formation of slowtwitch muscle fibres. Nature 418: 797-801.

Lowe R, Pountney DL, Jensen PH, Gai WP, Voelcker NH. 2004. Calcium(II) selectively induces $\alpha$-synuclein annular oligomers via interaction with the C-terminal domain. Protein Sci 13: 3245-3252.

Magyar K, Szende B. 2004. ( - )-Deprenyl, a selective MAO$\mathrm{B}$ inhibitor, with apoptotic and anti-apoptotic properties. Neurotoxicology 25: 233-242.

Mannhold R, Rekker RF, Sonntag C, ter Laak AM, Dross K, Polymeropoulos EE. 1995. Comparative evaluation of the predictive power of calculation procedures for molecular lipophilicity. J Pharm Sci 84: 1410-1419.

Matsuda W, Furuta T, Nakamura KC, Hioki H, Fujiyama F, Arai R, Kaneko T. 2009. Single nigrostriatal dopaminergic neurons form widely spread and highly dense axonal arborizations in the neostriatum. J Neurosci 29: 444-453.

Matthews RT, Ferrante RJ, Klivenyi P, Yang L, Klein AM, Mueller G, Kaddurah-Daouk R, Beal MF. 1999. Creatine and cyclocreatine attenuate MPTP neurotoxicity. Exp Neurol 157: 142-149.

Mattson MP. 2007. Calcium and neurodegeneration. Aging Cell 6: 337-350.

Matzuk MM, Saper CB. 1985. Preservation of hypothalamic dopaminergic neurons in Parkinson's disease. Ann Neurol 18: 552-555.

McCann MJ, Rogers RC. 1990. Oxytocin excites gastric-related neurones in rat dorsal vagal complex. J Physiol 428: 95-108.

McCormack JG, Halestrap AP, Denton RM. 1990. Role of calcium ions in regulation of mammalian intramitochondrial metabolism. Physiol Rev 70: 391-425. 
McMahon HT, Nicholls DG. 1991. The bioenergetics of neurotransmitter release. Biochim Biophys Acta 1059: 243-264.

Medvedev GS, Wilson CJ, Callaway JC, Kopell N. 2003. Dendritic synchrony and transient dynamics in a coupled oscillator model of the dopaminergic neuron. J Comput Neurosci 15: 53-69.

Mercer JN, Chan CS, Tkatch T, Held J, Surmeier DJ. 2007. Nav1.6 sodium channels are critical to pacemaking and fast spiking in globus pallidus neurons. J Neurosci 27: 13552-13566.

Mogami H, Nakano K, Tepikin AV, Petersen OH. 1997. Ca ${ }^{2+}$ flow via tunnels in polarized cells: Recharging of apical $\mathrm{Ca}^{2+}$ stores by focal $\mathrm{Ca}^{2+}$ entry through basal membrane patch. Cell 88: 49-55.

Morikawa H, Khodakhah K, Williams JT. 2003. Two intracellular pathways mediate metabotropic glutamate receptor-induced $\mathrm{Ca}^{2+}$ mobilization in dopamine neurons. J Neurosci 23: 149-157.

Mosharov EV, Larsen KE, Kanter E, Phillips KA, Wilson K, Schmitz Y, Krantz DE, Kobayashi K, Edwards RH, Sulzer D. 2009. Interplay between cytosolic dopamine, calcium, and $\alpha$-synuclein causes selective death of substantia nigra neurons. Neuron 62: 218-229.

Muller M, Cheung KH, Foskett JK. 2011. Enhanced ROS generation mediated by Alzheimer's disease presenilin regulation of InsP3R Ca ${ }^{2+}$ signaling. Antioxid Redox Signal 14: $1225-1235$.

Murphy MP. 2009. How mitochondria produce reactive oxygen species. Biochem J 417: 1-13.

Nath S, Goodwin J, Engelborghs Y, Pountney DL. 2011. Raised calcium promotes $\alpha$-synuclein aggregate formation. Mol Cell Neurosci 46: 516-526.

Nedergaard S, Flatman JA, Engberg I. 1993. Nifedipine- and $\omega$-conotoxin-sensitive $\mathrm{Ca}^{2+}$ conductances in guinea-pig substantia nigra pars compacta neurones. J Physiol 466: 727-747.

Nicholls D. 2002. Mitochondrial bioenergetics, aging, and aging-related disease. Sci Aging Knowledge Environ 2002: e12.

Nicholls DG, Johnson-Cadwell L, Vesce S, Jekabsons M, Yadava N. 2007. Bioenergetics of mitochondria in cultured neurons and their role in glutamate excitotoxicity. J Neurosci Res 85: 3206-3212.

Nielsen MS, Vorum H, Lindersson E, Jensen PH. 2001. $\mathrm{Ca}^{2+}$ binding to $\alpha$-synuclein regulates ligand binding and oligomerization. J Biol Chem 276: 22680-22684.

Paladini CA, Beckstead MJ, Weinshenker D. 2007. Electrophysiological properties of catecholaminergic neurons in the norepinephrine-deficient mouse. Neuroscience 144: 1067-1074.

Park MK, Petersen OH, Tepikin AV. 2000. The endoplasmic reticulum as one continuous $\mathrm{Ca}^{2+}$ pool: Visualization of rapid $\mathrm{Ca}^{2+}$ movements and equilibration. EMBO J 19: 5729-5739.

Park MK, Choi YM, Kang YK, Petersen OH. 2008. The endoplasmic reticulum as an integrator of multiple dendritic events. Neuroscientist 14: 68-77.

Pearl R. 1928. The rate of living, being an account of some experimental studies on the biology of life duration. Alfred A Knopf, New York.
Physiological Phenotype in Parkinson's Disease

Perez VI, Lew CM, Cortez LA, Webb CR, Rodriguez M, Liu Y, Qi W, Li Y, Chaudhuri A, Van Remmen H, et al. 2008. Thioredoxin 2 haploinsufficiency in mice results in impaired mitochondrial function and increased oxidative stress. Free Radic Biol Med 44: 882-892.

Perez VI, Bokov A, Van Remmen H, Mele J, Ran Q, Ikeno Y, Richardson A. 2009. Is the oxidative stress theory of aging dead? Biochim Biophys Acta 1790: 1005-1014.

Perez VI, Cortez LA, Lew CM, Rodriguez M, Webb CR, Van Remmen H, Chaudhuri A, Qi W, Lee S, Bokov A, et al. 2011. Thioredoxin 1 overexpression extends mainly the earlier part of life span in mice. J Gerontol A Biol Sci Med Sci 66: 1286-1299.

Pignatelli A, Kobayashi K, Okano H, Belluzzi O. 2005. Functional properties of dopaminergic neurones in the mouse olfactory bulb. J Physiol 564: 501-514.

Pignatelli A, Ackman JB, Vigetti D, Beltrami AP, Zucchini S, Belluzzi O. 2009. A potential reservoir of immature dopaminergic replacement neurons in the adult mammalian olfactory bulb. Pflugers Arch 457: 899-915.

Ping HX, Shepard PD. 1996. Apamin-sensitive $\mathrm{Ca}^{2+}$-activated $\mathrm{K}^{+}$channels regulate pacemaker activity in nigral dopamine neurons. Neuroreport 7: 809-814.

Ping HX, Shepard PD. 1999. Blockade of SK-type $\mathrm{Ca}^{2+}$. activated $\mathrm{K}^{+}$channels uncovers a $\mathrm{Ca}^{2+}$-dependent slow afterdepolarization in nigral dopamine neurons. J Neurophysiol 81: 977-984.

Pizzo P, Pozzan T. 2007. Mitochondria-endoplasmic reticulum choreography: Structure and signaling dynamics. Trends Cell Biol 17: 511-517.

Polymeropoulos MH, Lavedan C, Leroy E, Ide SE, Dehejia A, Dutra A, Pike B, Root H, Rubenstein J, Boyer R, et al. 1997. Mutation in the $\alpha$-synuclein gene identified in families with Parkinson's disease. Science 276: $2045-$ 2047.

Postuma RB, Lang AE, Massicotte-Marquez J, Montplaisir J. 2006. Potential early markers of Parkinson disease in idiopathic REM sleep behavior disorder. Neurology 66: 845-851.

Przedborski S, Vila M. 2003. The 1-methyl-4-phenyl1,2,3,6-tetrahydropyridine mouse model: A tool to explore the pathogenesis of Parkinson's disease. Ann NY Acad Sci 991: 189-198.

Przedborski S, Tieu K, Perier C, Vila M. 2004. MPTP as a mitochondrial neurotoxic model of Parkinson's disease. J Bioenerg Biomembr 36: 375-379.

Puopolo M, Bean BP, Raviola E. 2005. Spontaneous activity of isolated dopaminergic periglomerular cells of the main olfactory bulb. J Neurophysiol 94: 3618-3627.

Puopolo M, Raviola E, Bean BP. 2007. Roles of subthreshold calcium current and sodium current in spontaneous firing of mouse midbrain dopamine neurons. J Neurosci 27: 645-656.

Putzier I, Kullmann PH, Horn JP, Levitan ES. 2009. Cav1.3 channel voltage dependence, not $\mathrm{Ca}^{2+}$ selectivity, drives pacemaker activity and amplifies bursts in nigral dopamine neurons. J Neurosci 29: 15414-15419.

Rigoulet M, Yoboue ED, Devin A. 2011. Mitochondrial ROS generation and its regulation: Mechanisms involved in $\mathrm{H}_{2} \mathrm{O}_{2}$ signaling. Antioxid Redox Signal 14: 459-468. 
D.J. Surmeier et al.

Ritz B, Rhodes SL, Qian L, Schernhammer E, Olsen JH, Friis S. 2010. L-type calcium channel blockers and Parkinson disease in Denmark. Ann Neurol 67: 600-606.

Rizzuto R, Pozzan T. 2006. Microdomains of intracellular $\mathrm{Ca}^{2+}:$ Molecular determinants and functional consequences. Physiol Rev 86: 369-408.

Romo R, Schultz W. 1990. Dopamine neurons of the monkey midbrain: Contingencies of responses to active touch during self-initiated arm movements. J Neurophysiol 63: 592-606.

Rose CR, Konnerth A. 2001. Stores not just for storage: Intracellular calcium release and synaptic plasticity. Neuron 31: 519-522.

Saper CB, Sorrentino DM, German DC, de Lacalle S. 1991. Medullary catecholaminergic neurons in the normal human brain and in Parkinson's disease. Ann Neurol 29: $577-584$.

Schapira AH. 2011. Mitochondrial pathology in Parkinson's disease. Mt Sinai J Med 78: 872-881.

Scholze A, Plant TD, Dolphin AC, Nurnberg B. 2001. Functional expression and characterization of a voltagegated CaV1.3 $(\alpha 1 \mathrm{D})$ calcium channel subunit from an insulin-secreting cell line. Mol Endocrinol 15: 12111221.

Schriner SE, Linford NJ, Martin GM, Treuting P, Ogburn CE, Emond M, Coskun PE, Ladiges W, Wolf N, Van Remmen H, et al. 2005. Extension of murine life span by overexpression of catalase targeted to mitochondria. Science 308: 1909-1911.

Schwyn RC, Fox CA. 1974. The primate substantia nigra: A Golgi and electron microscopic study. J Hirnforsch 15: 95-126.

Serafin M, Khateb A, Muhlethaler M. 1990. Opiates inhibit pedunculopontine neurones in guinea pig brainstem slices. Neurosci Lett 119: 125-128.

Shastry BS. 2003. Neurodegenerative disorders of protein aggregation. Neurochem Int 43: 1-7.

Shimura H, Hattori N, Kubo S, Mizuno Y, Asakawa S, Minoshima S, Shimizu N, Iwai K, Chiba T, Tanaka K, et al. 2000. Familial Parkinson disease gene product, parkin, is a ubiquitin-protein ligase. Nat Genet 25: 302-305.

Shin JH, Ko HS, Kang H, Lee Y, Lee YI, Pletinkova O, Troconso JC, Dawson VL, Dawson TM. 2011. PARIS (ZNF746) repression of PGC- $1 \alpha$ contributes to neurodegeneration in Parkinson's disease. Cell 144: 689702.

Shults CW, Haas RH, Passov D, Beal MF. 1997. Coenzyme Q10 levels correlate with the activities of complexes I and II/III in mitochondria from parkinsonian and nonparkinsonian subjects. Ann Neurol 42: 261-264.

Simon KC, Gao X, Chen H, Schwarzschild MA, Ascherio A. 2010. Calcium channel blocker use and risk of Parkinson's disease. Mov Disord 25: 1818-1822.

Sinnegger-Brauns MJ, Huber IG, Koschak A, Wild C, Obermair GJ, Einzinger U, Hoda JC, Sartori SB, Striessnig J. 2009. Expression and 1,4-dihydropyridine-binding properties of brain L-type calcium channel isoforms. Mol Pharmacol 75: 407-414.

Smith RA, Murphy MP. 2011. Mitochondria-targeted antioxidants as therapies. Discov Med 11: 106-114.
Spillantini MG, Crowther RA, Jakes R, Hasegawa M, Goedert M. 1998. $\alpha$-Synuclein in filamentous inclusions of Lewy bodies from Parkinson's disease and dementia with Lewy bodies. Proc Natl Acad Sci 95: 6469-6473.

Stevens DR, Haas HL. 1996. Calcium-dependent prepotentials contribute to spontaneous activity in rat tuberomammillary neurons. J Physiol 493: 747-754.

Sulzer D, Zecca L. 2000. Intraneuronal dopamine-quinone synthesis: A review. Neurotox Res 1: 181-195.

Surmeier DJ, Guzman JN, Sanchez-Padilla J, Goldberg JA. 2010. The origins of oxidant stress in Parkinson's disease and therapeutic strategies. Antioxid Redox Signal 14: 1289-1301.

Taddese A, Bean BP. 2002. Subthreshold sodium current from rapidly inactivating sodium channels drives spontaneous firing of tuberomammillary neurons. Neuron 33: $587-600$.

Tamamizu-Kato S, Kosaraju MG, Kato H, Raussens V, Ruysschaert JM, Narayanaswami V. 2006. Calcium-triggered membrane interaction of the $\alpha$-synuclein acidic tail. Biochemistry 45: 10947-10956.

Trancikova A, Tsika E, Moore DJ. 2011. Mitochondrial dysfunction in genetic animal models of Parkinson's disease. Antioxid Redox Signal 16: 896-919.

Travagli RA, Gillis RA, Rossiter CD, Vicini S. 1991. Glutamate and GABA-mediated synaptic currents in neurons of the rat dorsal motor nucleus of the vagus. Am J Physiol 260: G531-G536.

Trifunovic A, Wredenberg A, Falkenberg M, Spelbrink JN, Rovio AT, Bruder CE, Bohlooly YM, Gidlof S, Oldfors A, Wibom R, et al. 2004. Premature ageing in mice expressing defective mitochondrial DNA polymerase. Nature 429: 417-423.

Van Remmen H, Ikeno Y, Hamilton M, Pahlavani M, Wolf N, Thorpe SR, Alderson NL, Baynes JW, Epstein CJ, Huang TT, et al. 2003. Life-long reduction in MnSOD activity results in increased DNA damage and higher incidence of cancer but does not accelerate aging. Physiol Genomics 16: 29-37.

Vekrellis K, Xilouri M, Emmanouilidou E, Rideout HJ, Stefanis L. 2011. Pathological roles of $\alpha$-synuclein in neurological disorders. Lancet Neurol 10: 1015-1025.

Verkhratsky A. 2005. Physiology and pathophysiology of the calcium store in the endoplasmic reticulum of neurons. Physiol Rev 85: 201-279.

Vermulst M, Bielas JH, Kujoth GC, Ladiges WC, Rabinovitch PS, Prolla TA, Loeb LA. 2007. Mitochondrial point mutations do not limit the natural lifespan of mice. Nat Genet 39: 540-543.

Vermulst M, Wanagat J, Kujoth GC, Bielas JH, Rabinovitch PS, Prolla TA, Loeb LA. 2008. DNA deletions and clonal mutations drive premature aging in mitochondrial mutator mice. Nat Genet 40: 392-394.

Votyakova TV, Reynolds IJ. 2001. $\Delta \Psi_{\mathrm{m}}$-Dependent and -independent production of reactive oxygen species by rat brain mitochondria. J Neurochem 79: 266-277.

Wallace DC. 2010. Mitochondrial DNA mutations in disease and aging. Environ Mol Mutagen 51: 440-450. 
Wider C, Foroud T, Wszolek ZK. 2010. Clinical implications of gene discovery in Parkinson's disease and parkinsonism. Mov Disord 25: S15-S20.

Williams JT, North RA, Shefner SA, Nishi S, Egan TM. 1984 Membrane properties of rat locus coeruleus neurones. Neuroscience 13: 137-156.

Wilson CJ, Callaway JC. 2000. Coupled oscillator model of the dopaminergic neuron of the substantia nigra. J Neurophysiol 83: 3084-3100.

Yamada T, McGeer PL, Baimbridge KG, McGeer EG. 1990. Relative sparing in Parkinson' disease of substantia nigra dopamine neurons containing calbindin-D28K. Brain Res 526: 303-307.

Zara V, Conte L, Trumpower BL. 2007. Identification and characterization of cytochrome $b c(1)$ subcomplexes in mitochondria from yeast with single and double deletions of genes encoding cytochrome $b c(1)$ subunits. FEBS J 274: 4526-4539.

Zigmond MJ, Abercrombie ED, Stricker EM. 1990. Partial damage to nigrostriatal bundle: Compensatory changes and the action of L-dopa. J Neural Transm Suppl 29: 217-232. 


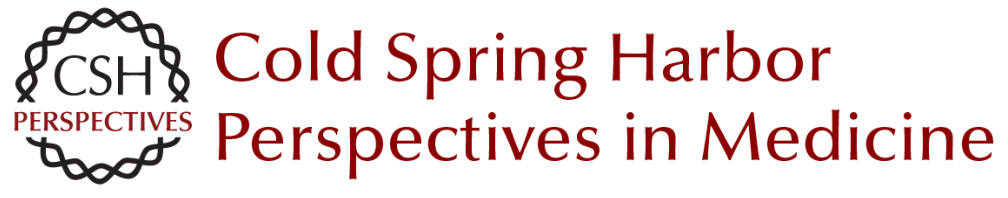

\section{Physiological Phenotype and Vulnerability in Parkinson's Disease}

D. James Surmeier, Jaime N. Guzman, Javier Sanchez and Paul T. Schumacker

Cold Spring Harb Perspect Med 2012; doi: 10.1101/cshperspect.a009290 originally published online May 2, 2012

\section{Subject Collection Parkinson's Disease}

Functional Neuroanatomy of the Basal Ganglia José L. Lanciego, Natasha Luquin and José A. Obeso

Animal Models of Parkinson's Disease: Vertebrate Genetics Yunjong Lee, Valina L. Dawson and Ted M. Dawson

Innate Inflammation in Parkinson's Disease V. Hugh Perry

Parkinson's Disease and Parkinsonism:

Neuropathology Dennis W. Dickson

Physiological Phenotype and Vulnerability in Parkinson's Disease

D. James Surmeier, Jaime N. Guzman, Javier Sanchez, et al.

Clinical Approach to Parkinson's Disease:

Features, Diagnosis, and Principles of Management João Massano and Kailash P. Bhatia

The Role of Autophagy in Parkinson's Disease Melinda A. Lynch-Day, Kai Mao, Ke Wang, et al.

Disruption of Protein Quality Control in Parkinson's Disease Casey Cook, Caroline Stetler and Leonard Petrucelli
Drosophila as a Model to Study Mitochondrial Dysfunction in Parkinson's Disease Ming Guo

Parkinsonism Due to Mutations in PINK1, Parkin, and DJ-1 and Oxidative Stress and Mitochondrial Pathways Mark R. Cookson

Programmed Cell Death in Parkinson's Disease Katerina Venderova and David S. Park

Genomics and Bioinformatics of Parkinson's Disease Sonja W. Scholz, Tim Mhyre, Habtom Ressom, et al.

Motor Control Abnormalities in Parkinson's

Disease Pietro Mazzoni, Britne Shabbott and Juan Camilo Cortés

Parkinson's Disease: Gene Therapies Philippe G. Coune, Bernard L. Schneider and Patrick Aebischer

Functional Neuroimaging in Parkinson's Disease Martin Niethammer, Andrew Feigin and David Eidelberg

Leucine-Rich Repeat Kinase 2 for Beginners: Six Key Questions Lauren R. Kett and William T. Dauer

For additional articles in this collection, see http://perspectivesinmedicine.cshlp.org/cgi/collection/ 